\title{
Segmentation and Holocene Behavior of the Middle Strand of the North Anatolian Fault (NW Turkey)
}

\author{
Y. Benjelloun ${ }^{1}$, J. de Sigoyer ${ }^{2}$, S. Garambois ${ }^{2}$, J. Carcaillet ${ }^{2}$, and Y. Klinger ${ }^{1}$ \\ ${ }^{1}$ Université de Paris, Institut de physique du globe de Paris, CNRS, F-75005 Paris, France. \\ ${ }^{2}$ Univ. Grenoble Alpes, Univ. Savoie Mont Blanc, CNRS, IRD, IFSTTAR, ISTerre, 38000 \\ Grenoble, France.
}

Corresponding author: Yacine Benjelloun (benjelloun@ipgp.fr)

\section{Key Points:}

- Systematic measurements of horizontal cumulative offsets along the middle strand of the North Anatolian fault

- Statistical analysis of the dataset allows to identify the last large ruptures along the fault and the associated slip per-segment

- Comparison with independent constraints on past earthquakes leads to discuss past rupture scenarios 


\section{Abstract}

The North Anatolian fault in the Marmara region is composed of three parallel strands all separated by $\sim 50 \mathrm{~km}$. The activity of the middle strand, which borders the southern edge of the Marmara Sea, is much debated because of its present-day very low seismicity. This contrasts with historical, archaeological and paleoseismological evidence, which suggest several destructive earthquakes have occurred during the last 2000 years. Our study aims to better constrain seismic hazard on the middle strand by exploring its Holocene paleoseismicity. For this, we mapped $148 \mathrm{~km}$ of the eastern part of the middle strand, using high-resolution satellite imagery. A series of landforms offset by the middle strand activity have been systematically measured to recover the past ruptures. Three Late PleistoceneHolocene terraces have been dated with the terrestrial cosmogenic nuclide method, constraining a horizontal slip rate of $\mathbf{4 . 4}_{-\mathbf{2} .8}^{+\mathbf{1 0 . 6}} \mathrm{mm} / \mathrm{yr}$. The statistical analysis of the offsets evidences several major ruptures preserved in the landscape, with coseismic lateral displacements ranging between 3 and $6.5 \mathrm{~m}$. This corresponds to $\mathrm{Mw} \sim 7.3$ earthquakes able to propagate along several fault segments. Historical seismicity and paleoseismology data suggest that the last large earthquakes along the MNAF happened in $1065 \mathrm{CE}$ and between the $14^{\text {th }}$ and $18^{\text {th }}$ centuries CE. Since then, the MNAF may have accumulated enough stress to generate a destructive rupture.

\section{Introduction}

Seismic hazard in the highly inhabited areas of northwestern Turkey is mainly related to the activity of the North Anatolian fault (NAF), a 1500-km long, dextral strike-slip structure that accommodates the relative motion between the Eurasian and Anatolian blocks (Ambraseys, 1970; Barka, 1992; Ketin, 1969; Sengör \& Zabci, 2019; Sengör et al., 2005), with a total 
geodetic slip estimated around 3 cm/yr (Fig. 1; McClusky et al., 2000; Meade et al., 2002). During the 20th century, the NAF ruptured almost entirely during a westward sequence of major earthquakes from Erzincan, in 1939, to Düzce and Izmit, in 1999 (Akyüz et al., 2002; Ambraseys, 2001a; Barka, 1996; Barka et al., 2002; Hubert-Ferrari et al., 2000; Stein et al., 1997). A seismic gap remains in the Sea of Marmara, in front of Istanbul, where a major earthquake is expected to occur in the next decades (Parsons et al., 2000). In addition to the main northern strand of the NAF, one should also consider the seismic hazard due to the presence of two secondary strands known as the middle and southern strands (MNAF and SNAF, Fig. 1). Although there are a large number of geodetic and geological slip rate estimates for the NNAF in the Marmara region (e.g. Dikbas et al., 2018; Ergintav et al., 2014; Grall et al., 2013; Kurt et al., 2013; Motagh et al., 2007; Reilinger et al., 2006), there are few studies for the southern strands (Zabci, 2019). These strands could together accommodate as much as $25 \%$ of the total slip of the NAF (Armijo et al., 2002; Flerit et al., 2003), with slip rates between 7 and less than $1 \mathrm{~mm} / \mathrm{yr}$ on the MNAF estimated with geodetical (Ergintav et al., 2014; Özbey et al., 2021; Reilinger et al., 2006) and geological data (Gasperini et al., 2011; Özalp et al., 2013; Vardar et al., 2014). While the SNAF experienced a Mw 7.2 earthquake in 1953 (Ketin \& Rösli, 1953; Kürçer et al., 2008, 2019), no major earthquake ruptured the MNAF during the instrumental period, and the seismicity of the MNAF zone during the last eight decades does not include more than a couple of earthquakes larger than Mw 5. The microseismicity recently recorded has been mostly located west of Iznik Lake and around the Gulf of Gemlik, while the other segments in the east have been characterized by much fewer events and appear quiescent compared with the neighboring NAF strands (Baris et al., 2002; Gürbüz et al., 2000; Öztürk et al., 2009; Tsukuda et al., 1988). These observations explain that the middle strand has often been overlooked in the assessment of deformation of the Marmara region (Le Pichon et al., 2014). This current quiescence contrasts 
with a significant historical seismic activity documented by several chronicles mentioning the destruction of Iznik and other surrounding cities located close to the MNAF during large earthquakes occurring in the last 2000 years (Ambraseys, 2002, 2009; Ambraseys \& Finkel, 1991; Ambraseys \& Jackson, 1998; Guidoboni \& Comastri, 2005; Fig. 2).

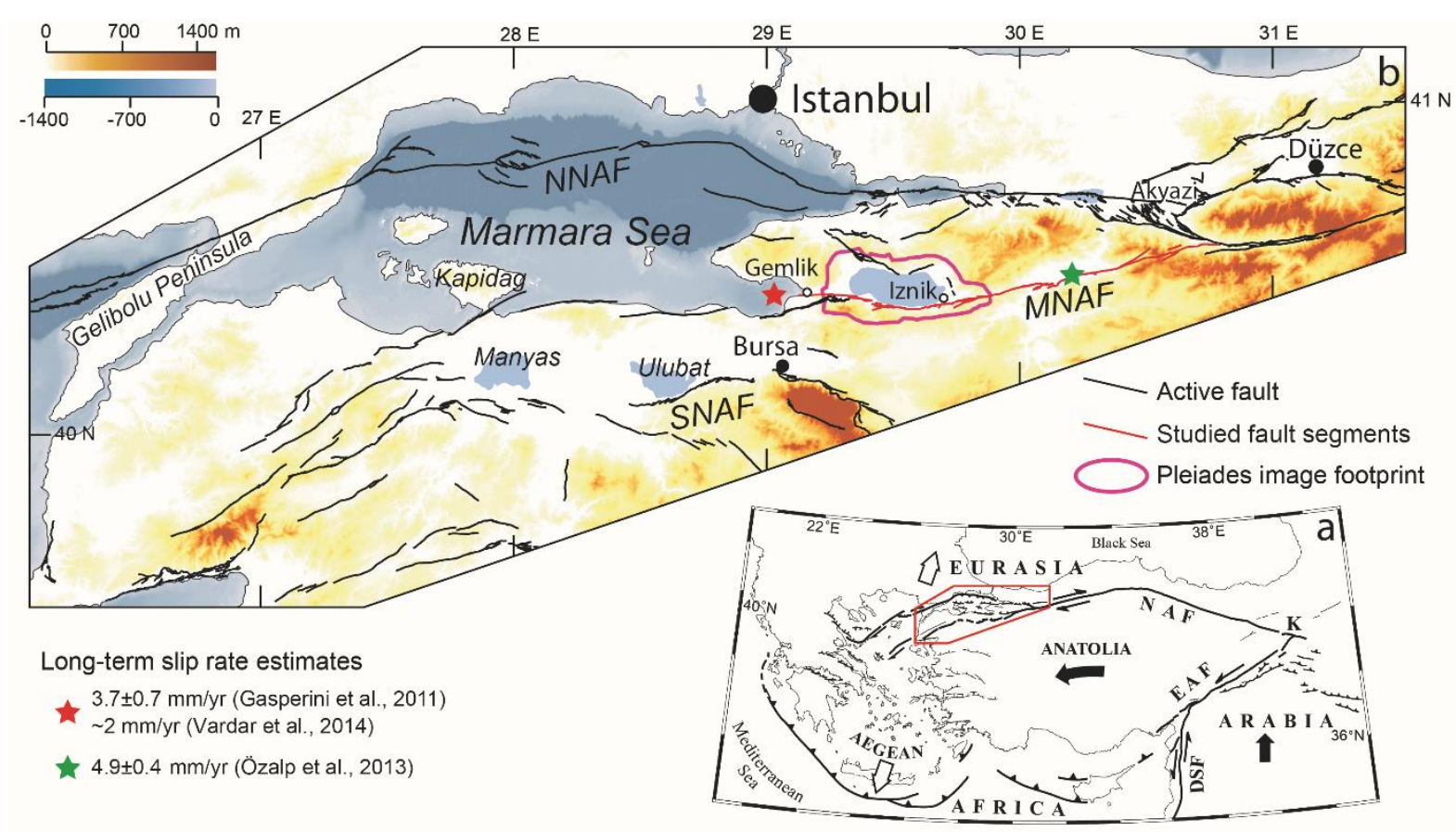

Figure 1. General tectonic context. (a) Schematic map of the main active fault zones of the Eastern Mediterranean (Armijo et al., 1999). NAF $=$ North Anatolian fault, EAF $=$ East Anatolian fault, DSF = Dead Sea fault. The red box surrounds the Marmara region. (b) Main active faults located within the Marmara region in black. The fault map was modified from Emre et al. (2011). NNAF, MNAF and SNAF refers to the northern, middle and southern strand of the NAF respectively. The bathymetry comes from the EMODnet Bathymetry Consortium (2018). The color stars locate fault sections where slip rates were estimated by geology or geomorphology studies (see Section 3 for details).

This article is protected by copyright. All rights reserved. 

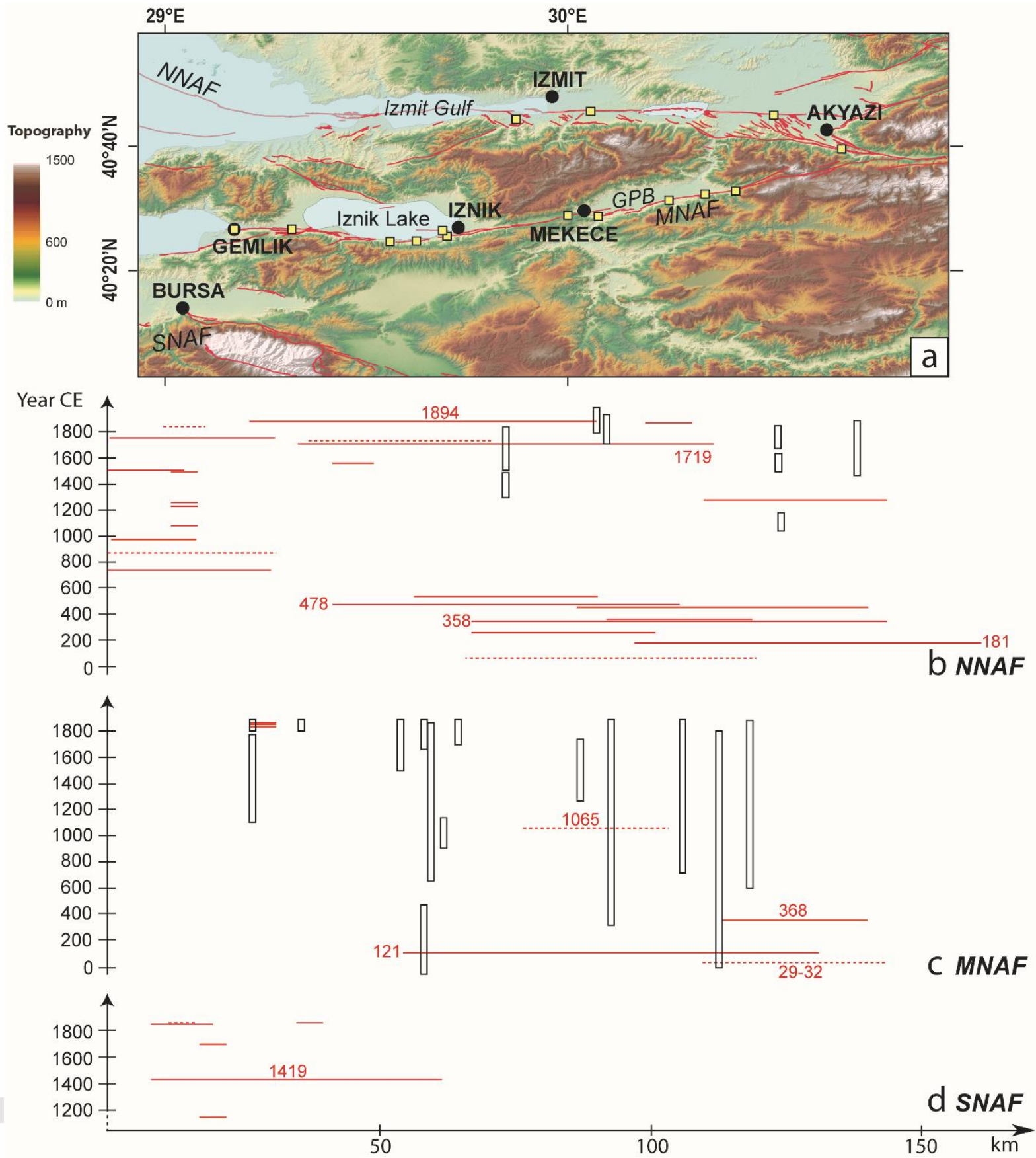

Figure 2. Historical seismicity of the eastern Marmara region before 1900 CE (Common Era).

(a) Active faults and main geographic features of the Marmara region. Trench sites are located with yellow boxes. GPB=Geyve-Pamukova Basin. (b, c, d) Historical earthquakes (horizontal red lines) and seismic events documented in palaeoseismological studies (vertical boxes) along the three strands of the NAF. The horizontal lines are positioned according to the epicentral areas interpreted from the sources. These epicentral areas are determined from the 
spatial distribution of the seismic intensities interpreted from historical descriptions, and their accuracy depends on the availability and quality of the written archives (Ambraseys et al., 2002). Dashed lines indicate less documented events. The length of each horizontal line corresponds to the approximate rupture length of the earthquake. To estimate this length, we rely on the magnitude estimated by historical seismology studies (see Table S1 in Supporting Information), from which a surface rupture length was derived using the relationship of Wells and Coppersmith (1984). The length of the vertical boxes corresponds to the dating of the events within $2 \sigma$ uncertainty (Civico et al., 2021; Dikbas et al., 2018; Dogan, 2010; Gastineau et al., 2021; Honkura \& Isikara, 1991; Ikeda, Suzuki et al., 1991; Klinger et al., 2003; Özalp et al., 2013; Rockwell et al., 2009; see Table S2 in Supporting Information for detailed data).

In the last decades, the development of high-resolution satellite imagery has made it possible to measure the deformation and characterize in great detail the geomorphology of tectonically active regions on a large scale (Elliott et al., 2016; Fu et al., 2004; Klinger et al., 2011; Ren et al., 2018). These images enable us to accurately map active faults along several tens of kilometers, to describe their segmentation and therefore provide useful information on the possible extension of a given rupture (e.g. Ansberque et al., 2016; Choi et al., 2018; Klinger et al., 2005). Such data also make it possible to document the long-term, cumulative slip distribution along the fault through inventories of offset geomorphological markers. This approach has been successfully employed since the 1960s on various faults to extract coseismic slip values from cumulative offset measurements, and to discuss the impact of segmentation in modulating the cumulative along-strike displacement (Ansberque et al., 2016; Barka, 1996; Manighetti et al., 2015, 2020; McGill and Rubin, 1999; Sieh and Jahns, 1984; Zielke et al., 2015; Kurtz et al., 2018).

In this study, we use a set of high-resolution images and topography measurements obtained

This article is protected by copyright. All rights reserved. 
from Pleiades data to map the eastern part of the MNAF between Gemlik and Akyazi district (Fig. 2a), and to measure a series of lateral displacements recorded by geomorphological markers, mainly stream talwegs and risers. To gather additional age control on the observed cumulative deformation, we sample and date three levels of wave-cut terraces formed around Iznik Lake. This enables us to constrain a Holocene horizontal slip rate for the central section of the MNAF. A statistical analysis of the offset measurements allows us to extract coseismic displacements for several of the largest past earthquakes and to discuss the slip distribution generated along the fault during these earthquakes. Comparison of these data with the historical seismicity record and previous paleoseismological data shows that this approach is not sensitive enough to detect the smaller events (Mw 6.8-7) that are also known to occur along the MNAF. We finally explore the implications of several plausible scenarios to explain past slip history at the scale of the NAF system east of the Marmara Sea.

\section{Geological context: the NAF in the Marmara region}

The formation of the NAF initiated some 11-13 Ma ago within a wider pre-existing shear zone which progressively localized through time (Sengör et al., 2005, 2014). Starting possibly from eastern Anatolia, the fault zone grew by westward propagation through the lithosphere over $\sim 10 \mathrm{Ma}$ and reached the northern Aegean between 5 and 1 Ma ago (Armijo et al., 1996, 1999; Barka, 1992). From the Messinian and during the Pliocene, the NAF has functioned as a narrow zone, cutting through and deforming several basins inherited from the previous tectonic stages (Barka, 1992; Y1lmaz et al., 1995). While the deformation is localized in a narrow zone in the eastern and central part of the NAF, it is structured on a wider area west of Düzce with a distribution of the deformation across several strands (Armijo et al., 1999; Fig. 1). The NAF strands show oblique kinematics, with local complex partitioning of the 
deformation between dextral strike-slip and extensional regimes (Koçyigit \& Özacar, 2003). The main northern strand (NNAF) continues along the strike of the main fault zone and crosses the northern part of the Marmara Sea from the Gulf of Izmit to Gelibolu Peninsula (Fig. 1). West of Akyazi district, another fault zone branches off from the NNAF, bounds to the south two successive basins known as the Geyve-Pamukova Basin and Iznik Lake, and reaches the south of the Marmara Sea through the Gulf of Gemlik as a single strand, which we term the middle strand of the NAF (MNAF) (Fig. 3a). West of Gemlik, this fault zone diffuses to a wider region (Sengör \& Zabci, 2019; Sengör et al., 2005). Between the Gemlik Gulf and the Kapidag peninsula, the active deformation seems to distribute across two parallel fault strands. While the MNAF continues along the southern shore of Marmara, a southern fault strand (SNAF) continues west-southwestwards to Ulubat and Manyas Lakes (Fig. 1b). Further west, the deformation becomes more diffuse with highly distributed faulting, so that it is no longer possible to distinguish independent MNAF and SNAF strands among this southern NAF zone.

The MNAF has been traditionally divided into three major sections over a total length of 135 km (Barka and Kadinsky-Cade, 1988; Fig. 3). (1) Between the Gulf of Gemlik and Iznik Lake, the fault shows a roughly E-W direction (segment A), until a $12 \mathrm{~km}$ long releasing bend around Sölöz delta, southwest of the Lake. (2) The fault follows the southern coast of Iznik Lake with an E-W orientation (segment C), and continues in the narrow valley of the Kirandere with a constant azimuth of $\sim 80^{\circ}$. This section in the west of Iznik Lake is marked by greater structural complexity and distribution of the deformation across several overlapping faults (segments D and E). Öztürk et al. (2009) suggested the existence of a continuous strike-slip fault extending along the deepest area of Iznik Lake, while Gastineau et al. (2021) evidenced an active fault strand following the northeastern edge of the lake's southern sub-basin, in a pull-apart configuration (Fig. 3b). East of Iznik Lake, Sipahioglu and 
Matsuda (1986) reported the presence of two lineaments in this section: a geological boundary fault with no marker of Quaternary activation, and an active fault strand crosscutting and deforming recent alluvium. The eastern end of this section around the town of Mekece consists in a narrow, $1 \mathrm{~km}$ wide releasing step-over. (3) East of the step-over, the MNAF borders the south of the Geyve-Pamukova basin with a $70-80^{\circ} \mathrm{N}$ strike (segments $\mathrm{F}$ and $\mathrm{G}$ ). The fault is associated to another fluvial system with the Sakarya River, collecting waters from the Anatolian plateau to the Black Sea. The river itself presents a large-scale right-lateral offset across the fault, estimated around 15-20 km (Fig. 3; Koçyigit, 1988; Özalp et al., 2013). The eastern edge of the basin is marked by a short restraining bend, after which the fault continues with a similar strike in the mountainous area of Akyazi where it connects to the main NAF (segment $\mathrm{H}$ ).

\section{Previous slip rates and paleoseismological studies on the MNAF}

Geodetical horizontal slip rates along the MNAF of $\sim 5 \pm 2 \mathrm{~mm} / \mathrm{yr}$ were derived from strain accumulation modeling of fault-perpendicular GPS measurement profiles, despite a poor spatial distribution of the GPS sites (Ergintav et al., 2014; Straub et al., 1997). Meade et al. (2002) reported a similar estimate of $4.9 \pm 2.0 \mathrm{~mm} / \mathrm{yr}$ for the segments east of Iznik using a GPS-based block modeling study. A more recent block modeling study estimated slip rates decreasing westward, and ranging between $4.2 \pm 1.3 \mathrm{~mm} / \mathrm{yr}$ close to the MNAF-NAF junction and 3.1 $\pm 1.5 \mathrm{~mm} / \mathrm{yr}$ north of Manyas Lake (Fig. 2; Özbey et al., 2021). By comparison, the geodetic slip rate estimates along the NNAF in the Marmara region range at $20-25 \mathrm{~mm} / \mathrm{yr}$, with a lower horizontal rate of $\sim 15 \mathrm{~mm} / \mathrm{yr}$ in the Cinarcik basin south of Istanbul (Zabci, 2019).

The geological slip rates measured along the NNAF show lower values ranging at $15-20$

This article is protected by copyright. All rights reserved. 
$\mathrm{mm} / \mathrm{yr}$ for the last $20 \mathrm{ka}$ (Zabci, 2019). On the MNAF, a long-term horizontal slip rate was estimated by Gasperini et al. (2011) who used the displaced edge of a 11,250 years old submerged delta in Gemlik Bay to derive a $3.7 \pm 0.7 \mathrm{~mm} / \mathrm{yr}$ minimal rate (Fig. 1b). This value was disputed by Vardar et al. (2014) who relied on a different offset value and an age of 30,000 years and derived a slip rate on the order of $2 \mathrm{~mm} / \mathrm{yr}$. Another value of $4.9 \pm 0.4 \mathrm{~mm} / \mathrm{yr}$ was derived from the $16 \pm 1 \mathrm{~km}$ long offset of the Sakarya river in the Pamukova plain since the Late Pliocene (Özalp et al., 2013). The vertical motion was documented by Ikeda et al. (1991) who estimated a 0.7-1.4 mm/yr minimal rate from tilted post-glacial beachridges located on the western shore of Iznik Lake.

This article is protected by copyright. All rights reserved. 

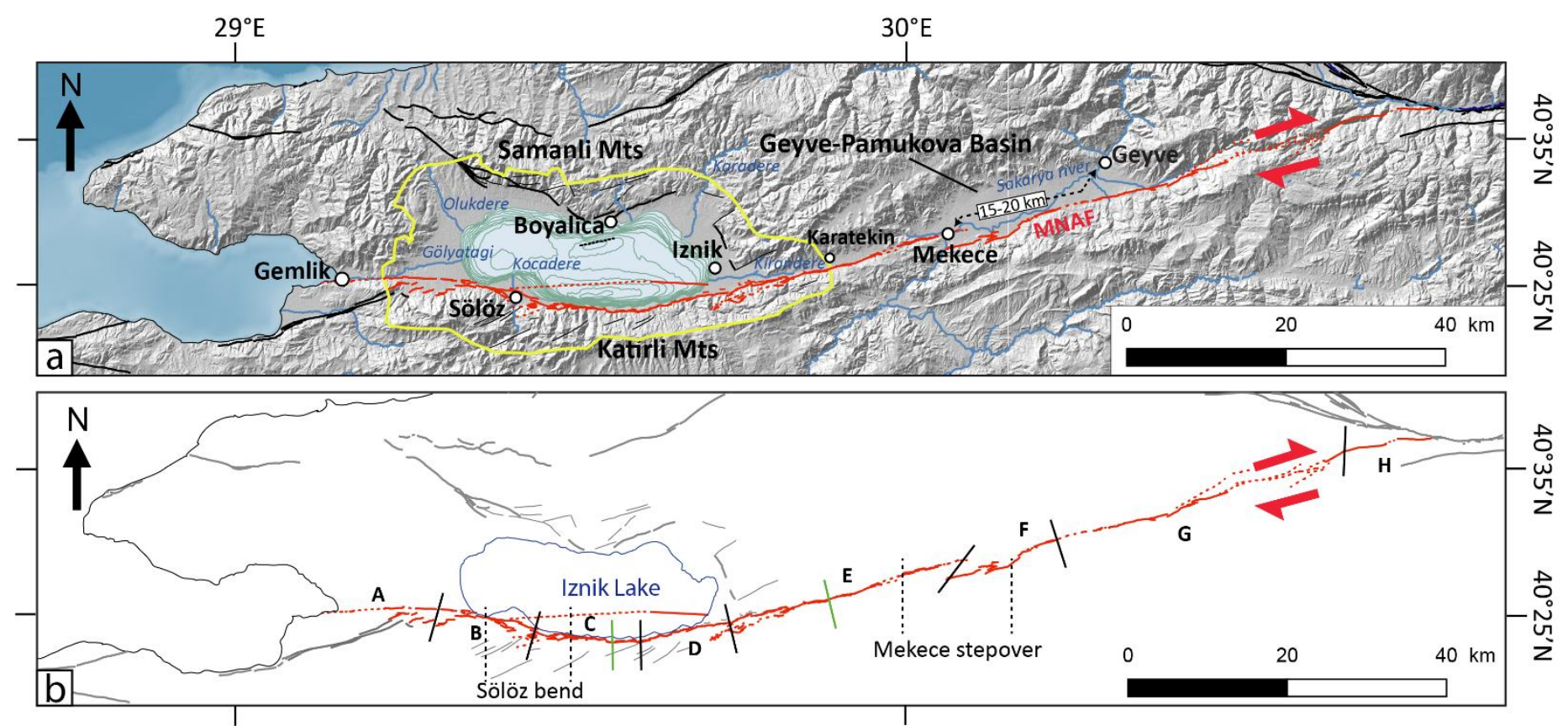

Figure 3. (a) General morphology of the eastern MNAF region. The footprint of the orthorectified Pleiades images (yellow) is superimposed on the Shuttle Radar Topography Mission (SRTM) model. The main rivers are drawn in blue. The MNAF is represented in red and the other active faults in black. Dotted lines indicate low confidence fault mapping (see section 4.2). The contours on the Iznik lake bottom are at a 5-meter interval (see Data Availability section). The fault traces within Iznik Lake are taken from Gastineau et al. (2021). (b) Segmentation of the main fault section analyzed in this study. Determined intersegments are located with black lines and alternative intersegments C/D et D/E with green lines (see section 4.3). Sölöz and Mekece step-overs' extent is shown with dashed lines. 
1 A significant number of paleoseismological trenches have been dug along the MNAF (see e.g.

2 the syntheses of Akyuz \& Zabci, 2012; Fraser et al., 2010) that led to the identification of several

3 ruptures during the last 4000 years (Fig. 2c). Yoshioka and Kusçu (1994) studied a site near

4 Geyve and identified a $3^{\text {rd }}$ century BCE rupture and a later undated one. In the same area, an

5 unpublished trenching work by Akyüz et al. (2014) led to the identification of three presumed

6 earthquakes. In the east of Iznik, the last rupture was dated between the $13-14^{\text {th }}$ and $18^{\text {th }}$ centuries

7 CE (Honkura \& Isikara, 1991; Ikeda, 1988). On the same segment, Barka (1993) opened nine

8 trenches and found three ruptures since $\sim 2000 \mathrm{BCE}$, but none of them were dated precisely. In

9 the eastern part of Iznik Lake, Gastineau et al. (2021) evidenced a historical event in sediment

10 cores, that they correlated to the 1065 CE earthquake. South of the lake, Erginal et al. (2021)

11 reported a $50 \mathrm{~cm}$ high coseismic scarplet in beachrock deposits that they attributed to an $8^{\text {th }}$

12 century rupture. On the same segment, Civico et al. (2021) opened two trenches and evidenced

13 one mid- $19^{\text {th }}$ century event, one penultimate event after the late $7^{\text {th }}$ century and two older events

14 before the mid- $5^{\text {th }}$ century CE. West of Iznik Lake, Ikeda et al. (1989) proposed a mid-19

15 century event from archaeological remains found in a natural fault exposure. In Gemlik, Özalp et

16 al. (2013) found a similar age for the last event and dated the penultimate between the $12^{\text {th }}$ and

$1718^{\text {th }}$ centuries. So far, the largest trenching work has been conducted by Dogan (2010) who

18 opened 11 trenches on various MNAF segments. In many cases, very few or no age data could

19 be retrieved, which makes it difficult to discuss whether the identified ruptures are independent

20 from each other. Thus, in terms of earthquake recurrence, the paleoseismological data along the

21 MNAF remain largely inconclusive due to partial results or occasionally contradictory findings

22 (Fig. 2c).

This article is protected by copyright. All rights reserved. 


\section{$24 \quad 4$ Fault geometry and segmentation analysis}

\section{$25 \quad 4.1$ Imagery datasets used}

26 Four stereo-pairs of Pleiades images covering the area between the Gulf of Gemlik, Iznik Lake, 27 and Karatekin (Fig. 3a) were processed to obtain a high-resolution DEM using the NASA Ames 28 Stereo Pipeline (ASP) software (Broxton and Edwards, 2008; Moratto et al., 2010; Shean et al., 29 2016) without using ground control points (Fig. 4c,d). The original Pleiades images have a 30 resolution of about $50 \mathrm{~cm}$, while the derived DEM has a horizontal resolution of $2 \mathrm{~m}$ and an

31 absolute vertical precision better than $10 \mathrm{~m}$. The DEM was then used to orthorectify the original 32 optical images with the same ASP software. For the area east of 29.88E, which was not covered 33 by our Pleiades images, we relied on Google Earth images (Pleiades images from CNES/Airbus, 34 and QuickBird and WorldView images from Maxar Technologies), the SRTM elevation model 35 and the active fault map of Emre et al. (2011).

\section{$36 \quad 4.2$ Fault mapping and along-strike geomorphology}

37 The trace of the MNAF between Karsak pass and Akyazi was mapped using the satellite imagery 38 described in the previous section and complementary observations gathered in the field (Fig. 2a,

39 4). In the area benefiting from Pleiades coverage, secondary faults north and east of Iznik Lake

40 were also mapped (Fig. 3). To locate the fault trace, we especially relied on high confidence

41 geomorphological features, such as series of horizontally offset gullies and ridges, shutter ridges,

42 well-defined scarps and facets. Along some other sections, particularly those lacking multiple

43 consistent offsets, the mapping relied on lower confidence features, including large scale

44 lineaments and slope breaks (Fig. 4). 

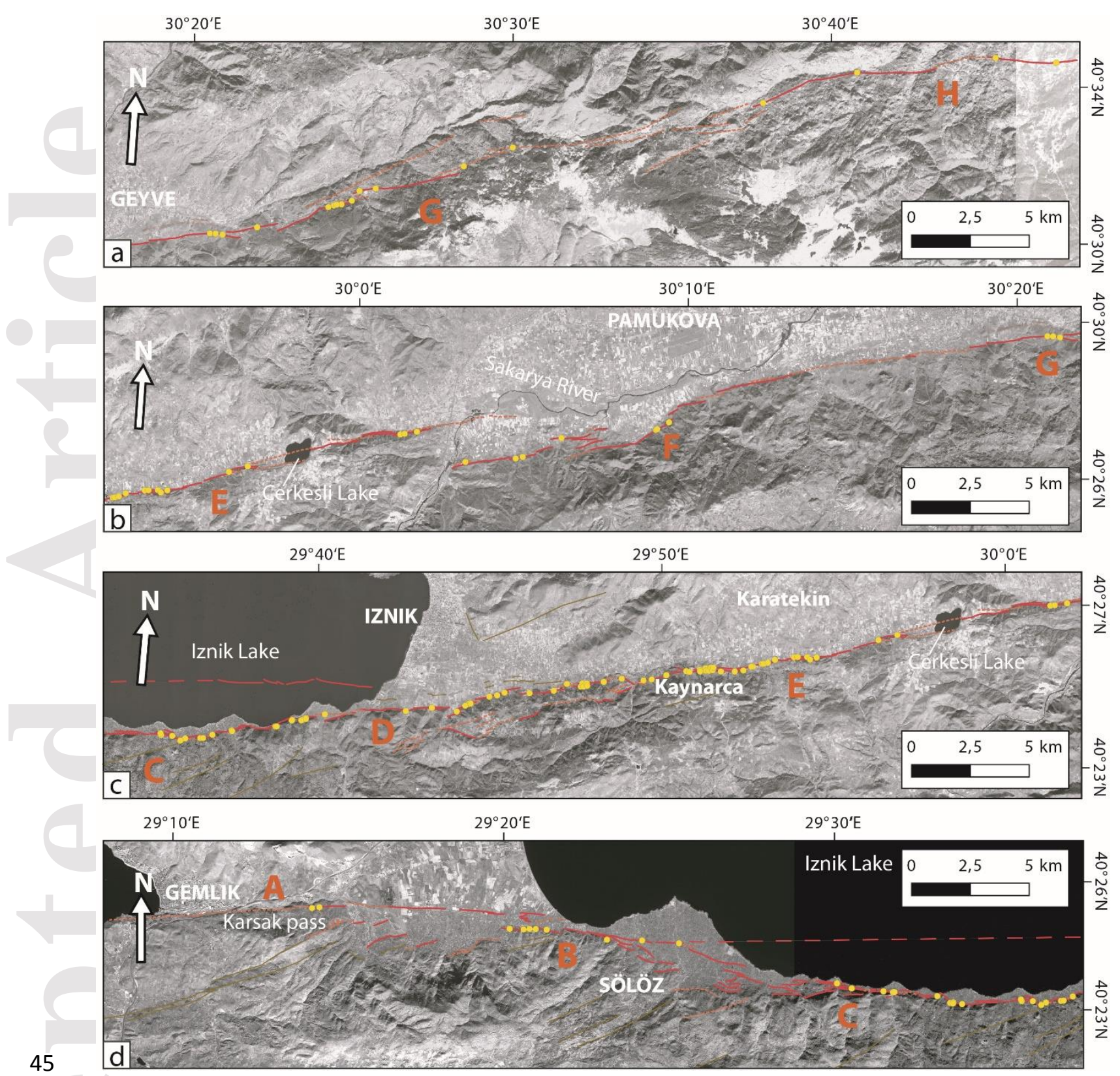

46 Figure 4. Surface trace of the eastern MNAF, superimposed on the Pleiades orthorectified

47 images around Iznik Lake and Sentinel 2 images (Copernicus Sentinel Data [2018]) in other

48 areas. Solid thick, dotted, and thin red lines refer to high confidence, low confidence, and

49 secondary fault mapping, respectively. Other active faults are drawn in green. The subaqueous

50 fault trace is taken from Gastineau et al. (2021). The yellow dots locate the markers associated

51 with the offsets measured. The areas (a to d) are presented from east to west. Our proposed

This article is protected by copyright. All rights reserved. 
52 segmentation (A to $\mathrm{H}$ ) is also displayed.

53 Evidence for late Quaternary deformation can be observed in the landscape along the MNAF 54 segments between the Gulf of Gemlik and Akyazi district (Fig. 2a, 3, 4). East of the Gulf of

55 Gemlik, a small, E-W trending fault scarp borders the south of Gemlik alluvial plain and runs 56 along the narrow Karsak pass (Fig. 4d). East of Karsak pass, several parallel faults stretch

57 between the Eocene sedimentary rocks of the mountain range and the derived wide alluvial fan

58 south of the Gölyatagi stream (Fig. 3a, 4d). Southwest of Iznik Lake, a set of overlapping and en

59 echelon fault scarps are visible between the basement rocks and the Holocene alluvium of the 60 large Sölöz delta, striking WNW-ESE. However, the horizontally offset markers are found along

61 an E-W fault strand crossing the delta and forming a releasing bend with the fault section

62 running south of the lake.

63 East of the delta, the fault shows again an E-W orientation with a succession of short, en echelon,

64 recent scarps in the narrow coastal plain south of the lake (Fig. 4c, d). The association of several

65 laterally offset gullies and vertical, south-facing scarplets (Fig. S1 and S2c) evidences the recent

66 dextral motion across the fault with a normal component. A series of significant triangular facets

67 have developed in the same section along the north-facing side of the Katirli range (Fig. 3a),

68 which suggests long-term cumulative normal deformation in addition to the strike-slip tectonics.

69 Southeast of the lake, the fault becomes more oblique to the main NAF direction, striking 80-

$7085^{\circ} \mathrm{N}$ (Fig. 4c). East of Iznik Lake, the fault follows the southern edge of a $15 \mathrm{~km}$ long narrow,

71 linear valley with a more continuous, simpler and straight trace (Fig. 4c). Between Iznik and

72 Kaynarca, large-scale lineaments mark an oblique branch extending south of the main fault zone

73 and striking $70^{\circ} \mathrm{N}$. On the main fault line, markers of strike-slip deformation, such as shutter

74 ridges, offset drainages and alluvial fan surfaces, are well developed (Fig. S2b). Occasionally, 
75 parallel or en echelon successive faults can be traced in the landscape. This is the case between

76 Kaynarca and Karatekin where secondary branching can be traced through a series of fan

77 surfaces showing several offsets (Fig. 4c). This geometrical complexity is associated with an

78 orientation change to $80^{\circ} \mathrm{N}$. Close to Mekece, a series of laterally displaced streams running

79 along a north facing scarp show cumulative dextral offsets ranging between $10 \mathrm{~m}$ and $25 \mathrm{~m}$.

80 Further east, the fault crosses the Sakarya river and forms a $\sim 1 \mathrm{~km}$ wide releasing step-over (Fig.

$814 b)$. The eastern section of the stepover is composed of shorter, en echelon faults. The fault then

82 follows the southern edge of the Geyve-Pamukova basin as a single, simple straight trace with a

$8370-80^{\circ} \mathrm{N}$, but is associated with fewer markers of Holocene horizontal deformation. East of the

84 Geyve plain, the fault runs in the middle of a mountainous area and the precise mapping of the

85 junction with the main NAF strand is less certain (Fig. 4a).

\section{$87 \quad 4.3$ Fault segmentation}

88 To properly interpret the set of deformed markers observed along the fault, it is needed to first

89 determine the fault segmentation. Such segmentation can also provide first-order constraints on

90 the maximum length and magnitude of earthquake that can be expected. The kind of boundary

91 between the successive segments (azimuth difference, width and length of the step-overs. . .) is

92 also thought to control whether a given rupture is likely to propagate through several segments

93 (Aki, 1984; Barka \& Kadinsky-Cade, 1988; Wesnousky, 2006). We decomposed the eastern

94 MNAF zone into several successive segments using the automatic procedure developed by

95 Klinger (2010). The digitized MNAF trace was first simplified and resampled each $50 \mathrm{~m}$. The

96 numerical method models the fault as a continuous set of linear segments and seeks, for a given

This article is protected by copyright. All rights reserved. 
97 number of segments, the distributions of segment boundaries which best approximate the actual

98 fault trace, using a $l_{1}$ trend filtering method (Kim et al., 2009). The brutal increase in the curve of

99 the RMS-misfit as a function of the number of segments indicates that a minimal range between

1008 and 19 segments is needed to describe the fault trace with a good trade-off between data-model

101 misfit and limited number of segments (Fig. S3). We especially explored this space of solutions

102 and found that the locations of most frequently selected inter-segments for this range cluster on

10312 points of the fault. Keeping the solutions that included the most visible geometrical

104 discontinuities along strike (e.g. Sölöz and Mekece stepovers, kinks at $29^{\circ} 35^{\prime}$ E and south of

105 Iznik) led us to favor a decomposition of the MNAF into 8 segments (denoted A to H on Fig.

$1063 b)$.

107 Overall, the boundaries most frequently selected correspond to the major strike change occurring

108 south of Iznik Lake (C/D inter-segment, Fig. 3b) and the releasing bend the eastern edge of the

109 Geyve-Pamukova basin (G-H inter-segment). The significant discontinuities of Sölöz bend (B/C

110 inter-segment) and Mekece stepover (E/F inter-segment) also correspond to recurrently selected

111 boundaries. Some other chosen boundaries are less recurrent. The D/E inter-segment is

112 associated with a minor variation in azimuth but also with a more visible change from multiple

113 parallel branches to a single, simpler fault trace eastward. The F/G inter-segment also reflects a

114 transition from small en echelon faults to a single linear fault line eastward.

115

1165 Cumulative and coseismic offsets

$117 \quad 5.1$ Method of measurement and uncertainties

This article is protected by copyright. All rights reserved. 
118 Major ground rupturing earthquakes generate meter-scale deformations that can be preserved in

119 the morphology through several seismic cycles (e. g. Ansberque et al., 2016; Klinger et al., 2011;

120 Kurtz et al., 2018). In the case of strike-slip ruptures, it is generally possible to measure in the

121 days following the earthquake a series of laterally displaced markers such as roads, fences, walls,

122 field or vegetation lines, terrace risers or gullies (Rockwell et al., 2002). Older morphological

123 markers can also show larger, cumulative values of offset representing the summation of several

124 coseismic displacements. If enough markers of various ages are preserved along the fault, the

125 compilation of a large number of offset measurements is expected to give several clusters of

126 values, corresponding to the cumulative displacement for various numbers of earthquakes

127 (Beauprêtre et al., 2012, 2013). The offset measurements carried out after recent earthquakes

128 have evidenced that the coseismic slip located on the fault often shows significant variations

129 along-strike, as high as 30-40\% around the mean displacement (Choi et al., 2018; Lin et al.,

130 2020; Reitman et al., 2019; Rockwell et al., 2002; Zielke, 2018). The off-fault deformation,

131 which is difficult to measure during post-seismic surveys, can also be significant (Antoine et al.,

132 2021; Choi et al., 2018; Rockwell et al., 2002). Despite the erosive and sedimentary processes

133 which tend to erase the smallest coseismic offsets, the measurement of cumulative offsets can

134 also give access to this slip variability on longer time scales (Rizza et al., 2011). 


\begin{tabular}{|c|c|c|c|c|c|c|c|c|c|}
\hline A) & Total & $\underset{\text { A }}{\text { Segment }}$ & $\begin{array}{c}\text { Segment } \\
\text { B }\end{array}$ & $\begin{array}{c}\text { Segment } \\
\mathrm{C}\end{array}$ & $\begin{array}{c}\text { Segment } \\
\text { D }\end{array}$ & $\begin{array}{c}\text { Segment } \\
\text { E }\end{array}$ & $\begin{array}{c}\text { Segment } \\
\text { F }\end{array}$ & $\underset{G}{\text { Segment }}$ & $\begin{array}{c}\text { Segment } \\
\text { H }\end{array}$ \\
\hline Length (full mapping, km) & 148 & 14.4 & 12.5 & 13.9 & 11.5 & 31.2 & 16.4 & 36.6 & 11.5 \\
\hline Length (confident mapping, km) & 107 & 4.1 & 12.5 & 13.6 & 11.1 & 24.1 & 14.9 & 17.3 & 9.2 \\
\hline Number of measurements & 114 & 2 & 10 & 14 & 15 & 50 & 7 & 12 & 4 \\
\hline Measured on Pleiades topography & 45 & 1 & 6 & 8 & 8 & 22 & 0 & 0 & 0 \\
\hline \% Pleiades topography & 39 & 50 & 60 & 57 & 53 & 44 & 0 & 0 & 0 \\
\hline Measured on Pleiades image & 32 & 1 & 4 & 6 & 7 & 14 & 0 & 0 & 0 \\
\hline$\%$ Pleiades image & 28 & 50 & 40 & 43 & 47 & 28 & 0 & 0 & 0 \\
\hline Measured on Google Earth image & 37 & 0 & 0 & 0 & 0 & 14 & 7 & 12 & 4 \\
\hline \% Google Earth image & 32 & 0 & 0 & 0 & 0 & 28 & 100 & 100 & 100 \\
\hline Mean quality /20 & 12 & 14 & 12 & 11.1 & 12.3 & 12.3 & 10.7 & 11.8 & 12.3 \\
\hline Density of data per km & 0.77 & 0.14 & 0.80 & 1.01 & 1.30 & 1.60 & 0.43 & 0.33 & 0.35 \\
\hline Density of data (confident mapping) & 1.07 & 0.49 & 0.80 & 1.03 & 1.35 & 2.07 & 0.47 & 0.69 & 0.43 \\
\hline Number of COPD peaks ( $2 \sigma$ model) & & & 5 & 7 & 11 & 8 & 4 & 6 & \\
\hline Number of COPD peaks ( $1 \sigma$ model) & & & 4 & 4 & 5 & 8 & 4 & 4 & 2 \\
\hline
\end{tabular}

137 Table 1. Summary of the main characteristics of the fault mapping and offset measurements datasets used in this study. 
140

141

142

143

Along a 148-km long portion of the eastern MNAF, we identified and systematically measured 114 offsets (Tables 1 and S3, see Data Availability section). $40 \%$ of the measurements were performed using Pleiades topographic data, while Pleiades ortho-rectified images and Google Earth images each represent $30 \%$ of the measurements. The displaced markers considered are river channels, gullies, terrace risers and more occasionally vegetation lines and ridges. We favored markers making a high angle with the fault in order to minimize the apparent offset linked to unaccounted-for vertical slip. For each marker, we define piercing lines, i.e. points that were aligned before the displacement, and that we project on the fault trace. The piercing points across the fault are then realigned by retro-deformation, which gives the offset value (Fig. 5). When one marker is displaced by several parallel fault strands, the offset value to be considered is the sum of the measurements on each fault line (Zielke et al., 2015). Five offsets were also measured in the field with tape (Fig. 6). One field measurement (marker 153) ranges significantly lower than the Pleiades measurement due to different reconstruction hypothesis. The other field measurements are in general in fair agreement with the values obtained from satellite imagery, though $\sim 10 \%$ lower on average. The relative underestimation of field offset measurements compared to satellite imagery has been noticed in previous studies (see another example in Klinger et al., 2005) suggesting that the distributed deformation is better assessed in the latter case (Antoine et al., 2021).

This article is protected by copyright. All rights reserved. 


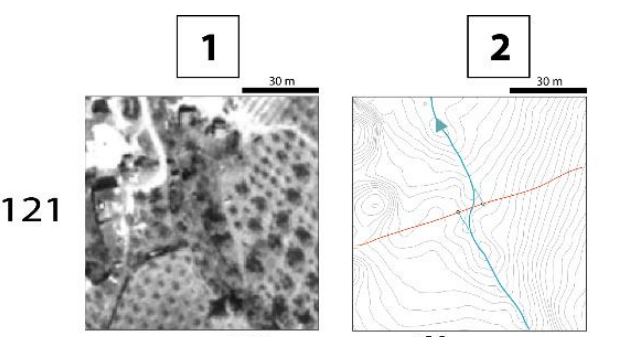

Offset $=11.0_{-0.5}^{+2.0} \mathrm{~m}$

$98 \mathrm{~b}$

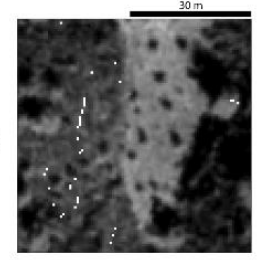

Offset $=5.0_{-2.0}^{+2.0} \mathrm{~m}$

13

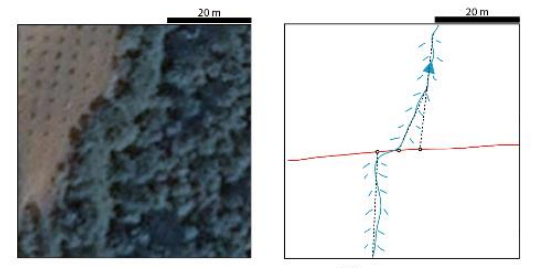

Offset $=6.0_{-1.0}^{+4.0} \mathrm{~m}$

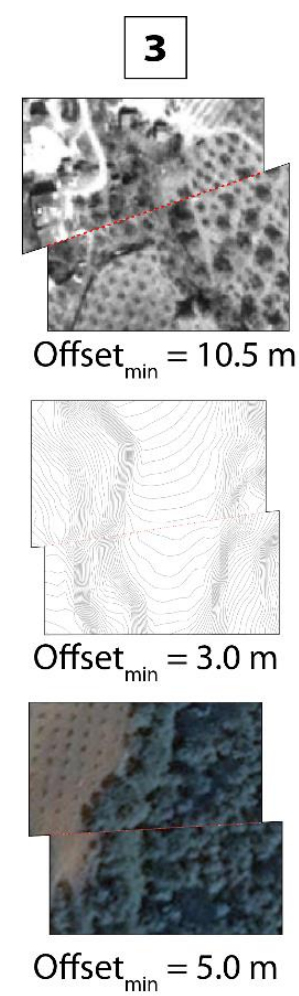

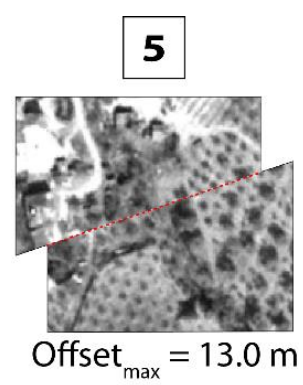
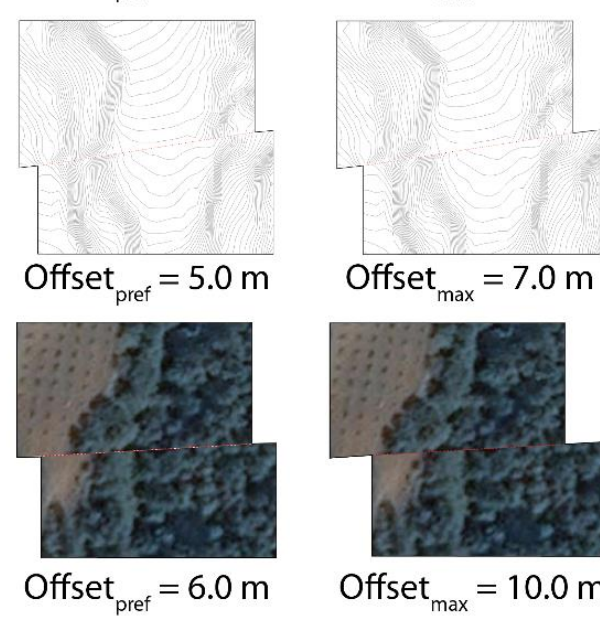

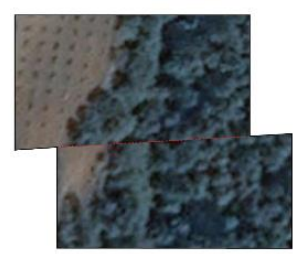

Offset $_{\max }=10.0 \mathrm{~m}$
162

163

164

165

166

167

168

169

170

171

Figure 5. Examples of horizontal offset measurements. Marker ID code is indicated on the

left. North direction is upward. From top to bottom, measurements were respectively done using the Pleiades image, topography, and the Google Earth image. Columns 1 and 2 show the original morphologies. The fault is drawn in red. Black lines and circles refer to the piercing lines and points. Columns 3, 4 and 5 show the retro-deformed morphologies giving the minimum, preferred and maximum offset values respectively. For the full dataset, see Data Availability section. 


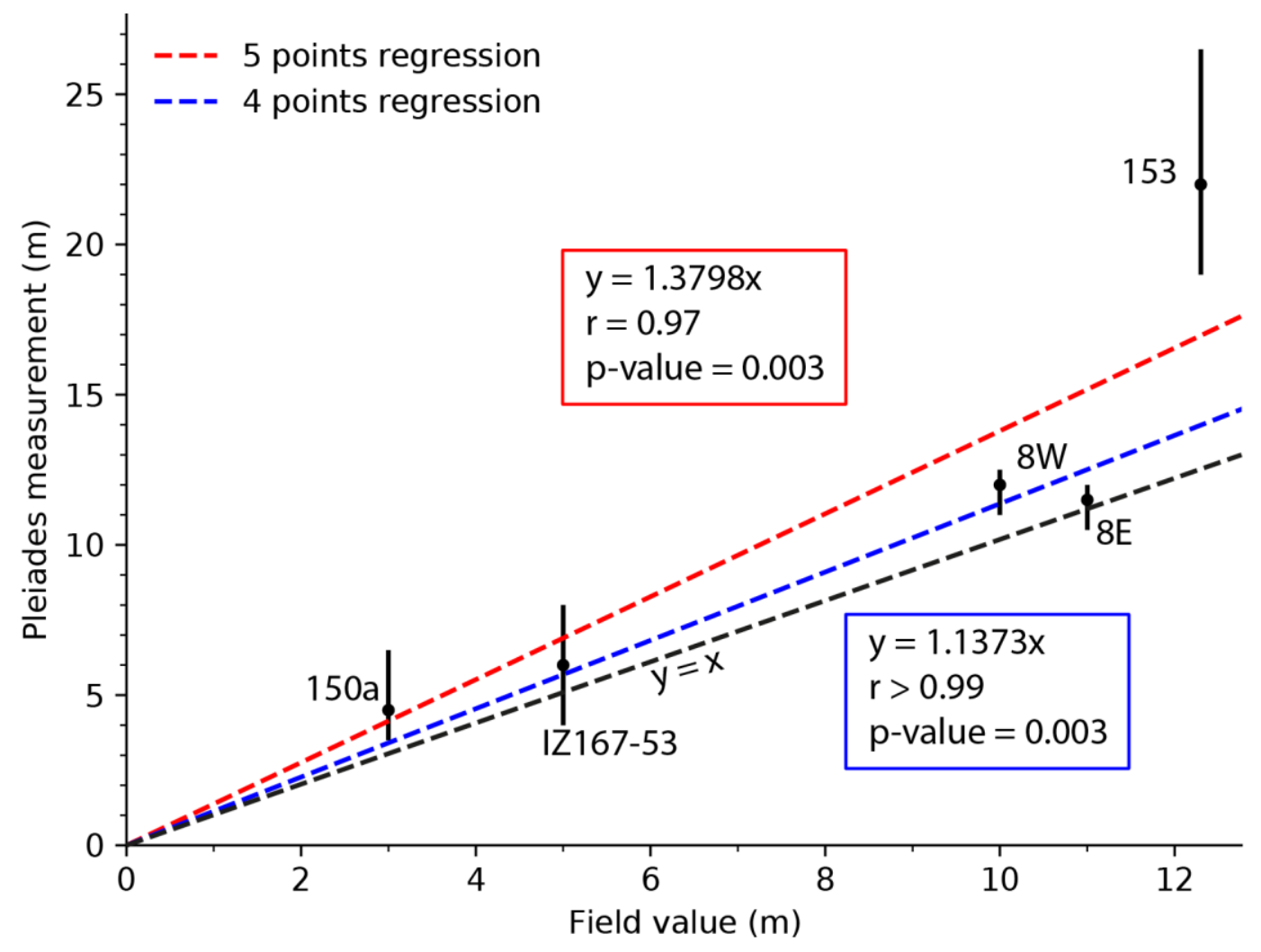

172

173 Figure 6. Comparison between field and Pleiades offset measurements. Two linear

174 regressions are shown, including all data points (red) and excluding marker 153 (blue). For

175 each regression we present the equation, Pearson's correlation coefficient $r$ and the p-value.

177 The uncertainty of the offset measurement mainly originates from the various possibilities for

178 interpreting and restoring the original, non-deformed geometry of the marker (Ansberque et

179 al., 2016; Manighetti et al., 2015). Therefore, each measurement consists in our preferred

180 value for the best reconstruction, and a minimum and a maximum value, each representing an

181 extreme plausible reconstruction. We use conservative min/max reconstructions, larger than

$182 \pm 15 \%$ of the preferred value on average, so that there is only a small probability that the real

183 offset falls out of this range (Gold et al., 2013). Each measurement is given a 20-points

184 quality score, which reflects the intrinsic quality of each marker in providing a relevant

185 measure (Beauprêtre et al., 2013; Choi et al., 2018; Kurtz et al., 2018; Zielke et al., 2012).

This article is protected by copyright. All rights reserved. 

(referred hereafter as " $1 \sigma$ model" and " $2 \sigma$ model"). Information).

\subsection{Statistical analysis}

This score includes the following criteria: (a) confidence that the offset marker is of tectonic nature and weakly man-modified, (b) degree of preservation (marker visibility and sharpness), (c) marker shape (width and sinuosity), (d) fault zone complexity (plausible fault zone width and number of fault splays), (e) angle of marker with fault, (f) resolution of used dataset (a detailed explanation of how the quality score is determined can be found in Supporting

The 114 offsets measured range between 2.5 and $64 \mathrm{~m}$, with a majority of values smaller than $30 \mathrm{~m}$ (Fig. 7b, Table S3). In order to identify the most significant offset clusters along each fault segment, which could represent the cumulative signature of past ruptures, we represent the offset values as probability density functions (e.g. Beauprêtre et al., 2012; Kurtz et al., 2018; McGill and Sieh, 1991; Zielke et al., 2010). Each offset measurement is represented with an asymmetric Gaussian distribution, the preferred measured value being the peak of the Gaussian probability density function (PDF). Since the minimum and maximum offsets reflect geologically plausible bounds for the reconstruction values and do not directly correspond to real standard variations (Scharer et al., 2014), we compare two models where these maximum and minimum ranges are taken as $\pm 1 \sigma$ and $\pm 2 \sigma$ half-widths of the PDF (referred hereafter as " $1 \sigma$ model" and " $2 \sigma$ model"). 

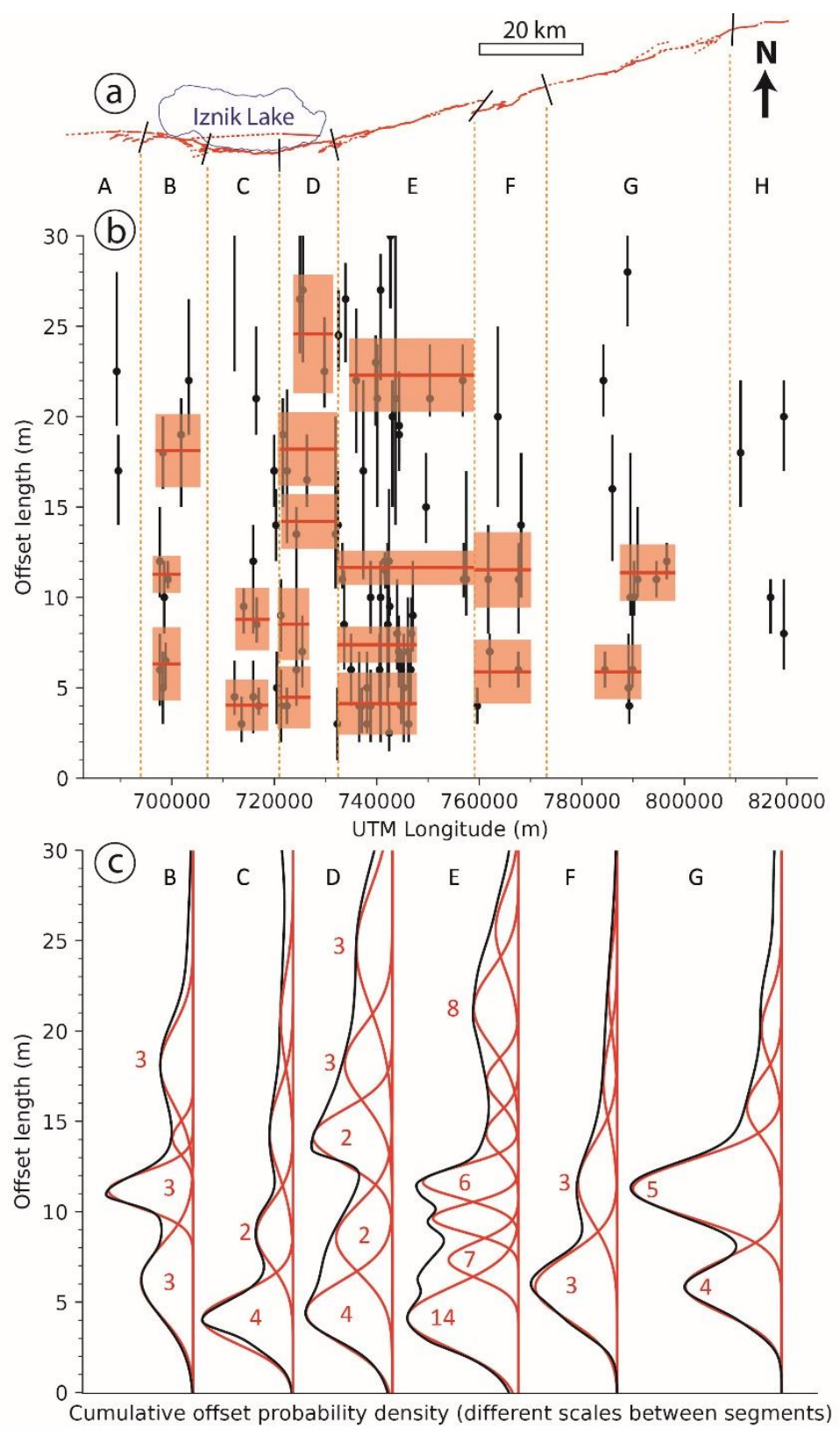

206

Figure 7. (a) Map of the fault section studied with our proposed segmentation. (b) Horizontal

208 offsets measured along the fault in the range 0-30 $\mathrm{m}$. The color boxes represent the best

209 constrained peak values, within $1 \sigma$ uncertainties, obtained on the cumulative offset probability

210 distribution (COPD) curves for each segment. The segments are separated by the vertical

211 orange broken lines. (c) COPD curves (black lines) and modeled average slips (red lines) for

212 the $1 \sigma$ model. The number of supporting individual measurements is indicated for the best

213 constrained COPD peaks.

This article is protected by copyright. All rights reserved. 
214 The individual PDFs for each segment are then summed into a cumulative offset probability

215 distribution (COPD) curve, using the quality scores as weights for each individual offset

216 measurement (Fig. 7c and 8a). The COPD generally presents local peak values, which indicate

217 the most frequent offsets measured along the fault section considered. The contribution of each

218 measurement in the shape of the COPD depends both on its uncertainty and on its quality score.

219 A larger uncertainty corresponds to a wider and flatter individual PDF, which consequently

220 contributes less to define a clear COPD peak. A lower quality score decreases the effect of the

221 measurement in changing the shape of the COPD. For each COPD curve, it is assumed that the

222 value associated to the first peak value corresponds to the offset related to the most recent large

223 earthquake preserved along that specific segment. The average slip associated with this last

224 rupture is empirically extracted from the COPD through several steps (Kurtz et al., 2018). (1)

225 The rising part of the COPD curve is used to build a symmetric Gaussian function, which

226 represents the modeled average slip associated to the most recent rupture along the segment

227 considered. (2) This modeled function is subtracted from the COPD to derive a residual COPD

228 (Fig. 8b). This residual curve is assumed to represent the cumulative tectonic deformation

229 recorded in the landscape before the most recent earthquake occurred. (3) In general, the rising

230 part of the COPD does not strictly follow a Gaussian function, which produces a residual

231 negative artefact located ahead of the following peak values. This residual is discarded by

232 resetting all negative values to zero before the next extraction. As these steps are iterated (Fig.

233 8c), the residual COPD curve flattens and the Gaussian fit becomes less constrained. To avoid

234 extracting artifacts which are not supported by measurements, the peaks with an amplitude below

$23510 \%$ of the maximum amplitude of the original COPD are judged unreliable and are discarded

236 (following Kurtz et al., 2018). The iterations are stopped when no additional peak can be

This article is protected by copyright. All rights reserved. 
237 constrained.

238 The validity of this method for extracting peaks and interpreting them as slip signals relies on

239 several assumptions. The resolution of satellite imagery and the uncertainties of offset

240 measurements limit the detection of small slip signals. In our case, this minimum detectable slip

241 ranges at $\sim 2.5 \mathrm{~m}$, which implies we cannot detect events of Mw below 7 . We assume that the

242 variability of coseismic slip over short distances along strike is limited enough to produce

243 relevant clusters of offset measurements. It is also assumed that these measurements result from

244 predominantly intermittent and seismogenic slip with negligible contributions of creep, slow slip

245 or afterslip. The production of geomorphic markers must happen more frequently than the large

246 earthquakes for the geomorphic slip record to be complete. The production of these markers is

247 also assumed to be stable over the time window considered. These assumptions will be addressed

248 together with the discussion of the results.

249 Interpreting COPD peaks as individual slip signals must be done with caution, especially when

250 relative measurement uncertainties are high and when only few data points are available along a

251 segment. Because of the natural variability in coseismic slip along strike, offset measurements

252 from a single event can produce bimodal distributions (Lin et al., 2020; McGill \& Rubin, 1999).

253 Conversely, one large increment might hide two separate, smaller events, but undistinguished

254 due to too few data and/or too large individual uncertainties (e. g. Liu-Zeng et al., 2006; Zielke et

255 al., 2010). Once the COPD peaks are extracted for a given segment, we assess the statistical

256 significance of each peak by looking at the following criteria (Tables 2 and 3): number of

257 supporting individual measurements, spreading of the data supporting the first two peaks, degree

258 of overlapping with preceding peak, sensitivity to alternative segmentation (for segments C, D,

$259 \mathrm{E})$.

This article is protected by copyright. All rights reserved. 

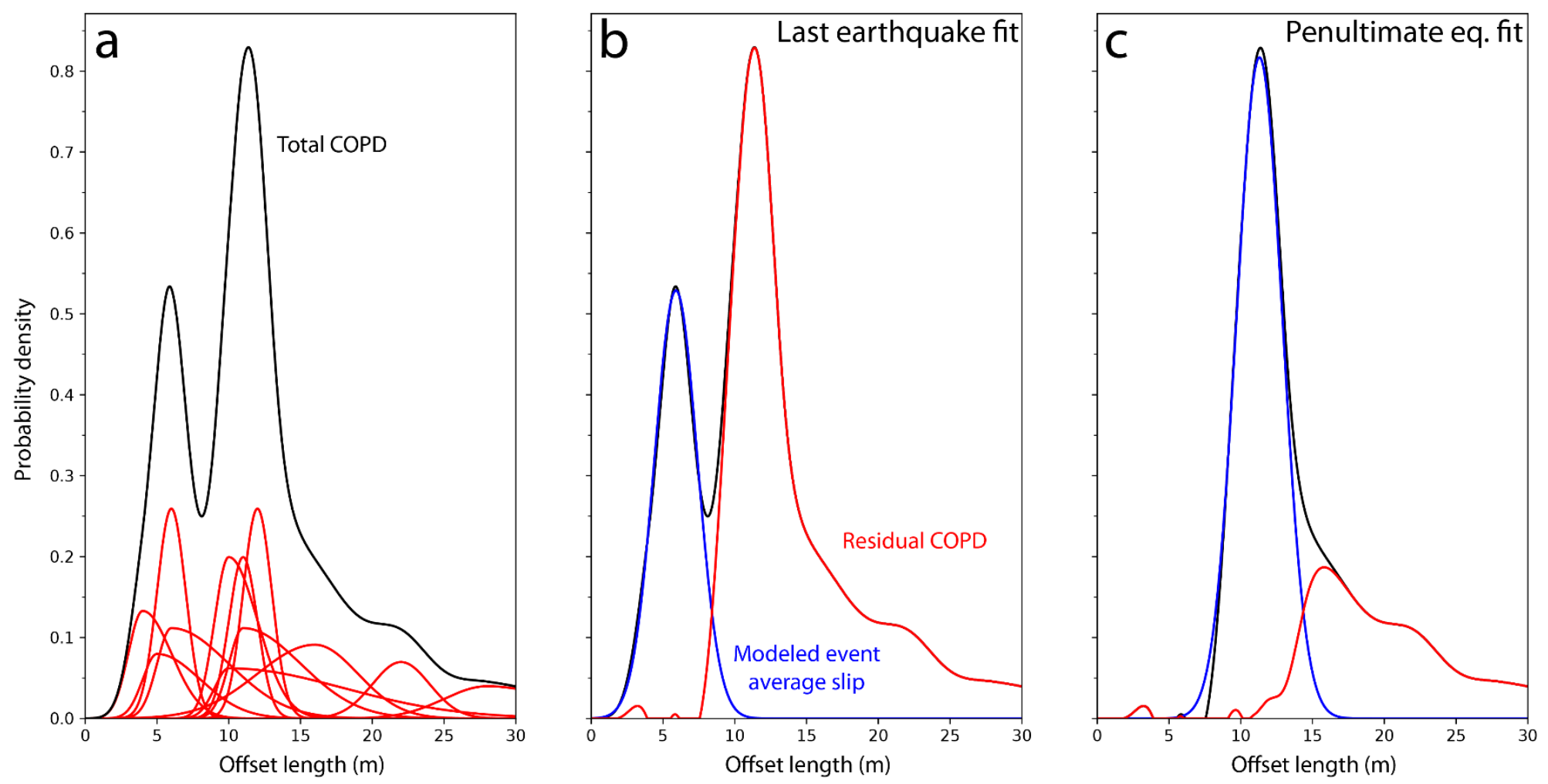

Figure 8. Illustration of the statistical analysis methodology used for the offset measurements of segment G. (a) Probability density functions of the individual measurements (in red) and corresponding Cumulative Offset Probability Density (COPD, in black). (b) Modeling of the last major surface rupture signal by fitting the increasing part of the COPD with a Gaussian curve (in blue). The red line is the residue of the COPD after subtracting this last rupture slip model. (c) Same process as (b) for the presumed penultimate event. 


\section{$265 \quad 5.3$ Results}

266 Tables 2 and 3 present the offset values extracted from the COPD peaks for each fault segment

267 in the range $0-30 \mathrm{~m}$. We extracted between 4 and 11 peaks per segment for the $2 \sigma$ model and

268 between 4 and 8 peaks for the $1 \sigma$ model (Table 1). Smaller modeled uncertainties tend to

269 increase the number of extracted peaks per segment. This effect is most significant for segment

$270 \mathrm{D}$ where the number of peaks for the $2 \sigma$ model is two times larger. However, most of the

271 extracted peaks for the $2 \sigma$ model show poor statistical robustness. Half of them are not supported

272 by more than one individual measurement (Table 3). For some of them, the increment with the

273 preceding peak is not significantly different from zero. Several of them do not pass the

274 segmentation test. This likely results from a high degree of data scattering compared to

275 uncertainties, especially for segments with small numbers of measurements. Segment E does not

276 show this feature because of its high spatial density of measurements, which is more than twice

277 as high as the average density of the other segments (Table 1).

278 To check for potential biases resulting from this higher density of measurements, we performed a

279 supplementary test on segment E. We produced and analyzed five random subsets of 18

280 measurements obtained on segment E, so that the measurement density of the subsets equals the

281 average density of the other segments, i.e. 0.75 measurement per $\mathrm{km}$. We then identified which

282 extracted peaks remained consistent between all subsets. The sensitivity tests for that segment

283 suggest that only the first two peaks are statistically robust. These peaks still present a high

284 degree of overlapping.

285 Most peaks obtained with the $1 \sigma$ model are statistically stronger than those obtained with the $2 \sigma$

286 model (Table 2). When only the more robust peaks are considered, both models show similar

This article is protected by copyright. All rights reserved. 
287 results (Table 4, Fig. 7b). Segments A and $\mathrm{H}$ did not provide statistically significant peaks due to 288 the very small number of measurements.

289 We identified two to five statistically robust cumulative slip increments for segments B to G, 290 ranging between 4 and $25 \mathrm{~m}$. Offset values show consistency between all segments for the first 291 two extracted peaks at $\sim 5$ and $\sim 10 \mathrm{~m}$. However, the central segments C, D and E show lower 292 mean values of increments, from $3.2 \mathrm{~m}$ to $4.7 \mathrm{~m}$, while they range between 5 and $6.2 \mathrm{~m}$ on 293 segments B, F and G. On segment E, despite the higher density of measurements, the events are 294 harder to separate and their respective displacement is less constrained due to the larger 295 scattering of data points. Peak values differ more for higher peaks (Table 4).

This article is protected by copyright. All rights reserved. 


\begin{tabular}{|c|c|c|c|c|c|c|c|c|c|c|}
\hline Segment & Mean value & $( \pm 1 \sigma)$ & $\begin{array}{l}\text { Increment with } \\
\text { preceding peak }\end{array}$ & $( \pm 1 \sigma)$ & $\begin{array}{c}\text { Number of } \\
\text { supporting } \\
\text { measurements } \\
\end{array}$ & $\begin{array}{c}\text { Mean } \\
\text { quality } \\
\end{array}$ & $\begin{array}{c}\text { Spreading with } \\
\text { previous peak }\end{array}$ & $\begin{array}{c}\text { Overlapping } \\
\text { coefficient with } \\
\text { previous peak }\end{array}$ & $\begin{array}{r}\text { Sensitivity to } \\
\text { segmentation }\end{array}$ & $\begin{array}{c}\text { Sensitivity to } \\
\text { downsampling }\end{array}$ \\
\hline $\mathrm{B}$ & 6.2 & 2 & $\left(x^{2}\right)$ & & 3 & 12.7 & & & & \\
\hline $\mathrm{B}$ & 11.2 & 1 & 5 & 3 & 3 & 12 & $<30 \%$ & 0.09 & & \\
\hline $\mathrm{B}$ & 14.1 & 0.9 & 2.9 & 1.9 & 0 & & & 0.13 & & \\
\hline $\mathrm{B}$ & 18.1 & 2.1 & 4 & 3 & 3 & 12 & & 0.16 & & \\
\hline $\mathrm{C}$ & 4.1 & 1.4 & 2 & & 4 & 14.3 & & & & \\
\hline $\mathrm{C}$ & 8.8 & 1.7 & 4.7 & 3.1 & 2 & 11 & $<30 \%$ & 0.13 & & \\
\hline $\mathrm{C}$ & 14.4 & 2.3 & 5.6 & 4 & 3 & 9 & & 0.16 & $\mathrm{x}$ & \\
\hline $\mathrm{C}$ & 20.6 & 2.5 & 6.2 & 4.8 & 1 & 11 & & 0.2 & & \\
\hline $\mathrm{D}$ & 4.5 & 1.7 & $\sqrt{1}$ & & 4 & 12.3 & & & & \\
\hline $\mathrm{D}$ & 8.6 & 1.9 & 4.1 & 3.6 & 2 & 10 & $<30 \%$ & 0.25 & & \\
\hline $\mathrm{D}$ & 14.2 & 1.5 & 5.6 & 3.4 & 2 & 14.5 & & 0.1 & & \\
\hline $\mathrm{D}$ & 18.2 & 2.1 & 4 & 3.6 & 3 & 14 & & 0.26 & & \\
\hline $\mathrm{D}$ & 24.6 & 3.3 & 6.4 & 5.4 & 3 & 11.3 & & 0.23 & & \\
\hline $\mathrm{E}$ & 4.2 & 1.7 & $C$ & & 14 & 12.8 & & & & \\
\hline $\mathrm{E}$ & 7.4 & 1 & 3.2 & 2.7 & 7 & 12.1 & $<30 \%$ & 0.23 & & \\
\hline $\mathrm{E}$ & 9.7 & 0.8 & 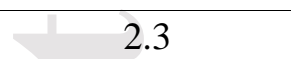 & 1.8 & 4 & 10.8 & & 0.2 & & $\mathrm{x}$ \\
\hline $\mathrm{E}$ & 11.7 & 0.9 & 2 & 1.7 & 6 & 13.3 & & 0.24 & & \\
\hline $\mathrm{E}$ & 14.4 & 1.1 & 2.7 & 2 & 2 & 11 & & 0.18 & & $\mathrm{x}$ \\
\hline $\mathrm{E}$ & 17.3 & 1.2 & 2.9 & 2.3 & 2 & 13 & & 0.21 & $\mathrm{x}$ & $\mathrm{x}$ \\
\hline $\mathrm{E}$ & 21.3 & 2.1 & 4 & 3.3 & 8 & 11.6 & & 0.21 & & \\
\hline $\mathrm{E}$ & 25.6 & 2.1 & 4.3 & 4.2 & 3 & 13.7 & & 0.31 & $\mathrm{x}$ & $\mathrm{x}$ \\
\hline $\mathrm{F}$ & 5.9 & 1.8 & $P>$ & & 3 & 10.7 & & & & \\
\hline $\mathrm{F}$ & 11.6 & 2.2 & 5.7 & 4 & 3 & 10 & $<30 \%$ & 0.15 & & \\
\hline $\mathrm{F}$ & 17.2 & 2.3 & 5.6 & 4.5 & 0 & & & 0.21 & & \\
\hline $\mathrm{F}$ & 22.3 & 2.3 & 5.1 & 4.6 & 1 & 13 & & 0.27 & & \\
\hline $\mathrm{G}$ & 5.9 & 1.5 & & & 4 & 11.3 & & & & \\
\hline
\end{tabular}




\begin{tabular}{cccccccccc}
\hline $\mathrm{G}$ & 11.3 & 1.6 & 5.4 & 3.1 & 5 & 13.2 & $<30 \%$ & 0.08 & \\
\hline $\mathrm{G}$ & 15.8 & 1.6 & 4.5 & 3.2 & 1 & 16 & & 0.16 & \\
\hline $\mathrm{G}$ & 20.1 & 1.8 & 4.3 & 3.4 & 1 & 7 & & 0.21 & \\
\hline $\mathrm{H}$ & 9.4 & 2 & & & 2 & 13 & & & \\
\hline $\mathrm{H}$ & 18.7 & 2.7 & 9.3 & 4.7 & 2 & 11.5 & $30-40 \%$ & 0.05 & \\
\hline
\end{tabular}

296 Table 2. COPD peaks extracted for the $1 \sigma$ model. Mean quality is computed on the set of individual measurements supporting each

297 peak. Spreading value is expressed in \% of the mean of measurements supporting the first two peaks per segment. The overlapping

298 coefficient is computed using normalized distributions.

\begin{tabular}{|c|c|c|c|c|c|c|c|c|c|c|}
\hline Segment & $\begin{array}{l}\text { Mean } \\
\text { value }\end{array}$ & $( \pm 1 \sigma)$ & $\begin{array}{l}\text { Increment with } \\
\text { preceding peak }\end{array}$ & $( \pm 1 \sigma)$ & $\begin{array}{c}\text { Number of } \\
\text { supporting } \\
\text { measurements }\end{array}$ & $\begin{array}{c}\text { Mean } \\
\text { quality }\end{array}$ & $\begin{array}{c}\text { Spreading with } \\
\text { previous peak }\end{array}$ & $\begin{array}{l}\text { Overlapping } \\
\text { coefficient with } \\
\text { previous peak }\end{array}$ & $\begin{array}{l}\text { Sensitivity to } \\
\text { segmentation }\end{array}$ & $\begin{array}{c}\text { Sensitivity to } \\
\text { downsampling }\end{array}$ \\
\hline $\mathrm{B}$ & 6.1 & 1.3 & 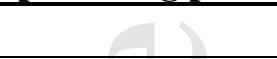 & & 3 & 12.7 & & & & \\
\hline $\mathrm{B}$ & 9.9 & 0.6 & 3.8 & 1.9 & 1 & 13 & $<30 \%$ & 0.04 & & \\
\hline $\mathrm{B}$ & 11.1 & 0.4 & 1.2 & 1 & 1 & 15 & & 0.22 & & \\
\hline $\mathrm{B}$ & 12.3 & 0.9 & 1.2 & 1.3 & 1 & 8 & & 0.32 & & \\
\hline $\mathrm{B}$ & 18.2 & 1.4 & 5.9 & 2.3 & 2 & 13.5 & & 0.01 & & \\
\hline $\mathrm{C}$ & 3 & 0.5 & ras & & 1 & 17 & & & & \\
\hline $\mathrm{C}$ & 4.2 & 0.5 & 1.2 & 1 & 3 & 13.3 & $>40 \%$ & 0.23 & & \\
\hline $\mathrm{C}$ & 5.4 & 0.5 & 1.2 & 1 & 0 & & & 0.23 & & \\
\hline $\mathrm{C}$ & 9 & 0.8 & 3.6 & 1.3 & 3 & 10 & $<30 \%$ & 0.05 & & \\
\hline $\mathrm{C}$ & 13.9 & 1.6 & 4.9 & 2.4 & 1 & 11 & & 0.04 & $\mathrm{x}$ & \\
\hline $\mathrm{C}$ & 17.2 & 0.7 & 3.3 & 2.3 & 1 & 8 & & 0.14 & $\mathrm{x}$ & \\
\hline $\mathrm{C}$ & 21.2 & 1.6 & 4 & 2.3 & 1 & 11 & & 0.07 & & \\
\hline $\mathrm{D}$ & 4.2 & 0.8 & & & 3 & 14 & & & & \\
\hline $\mathrm{D}$ & 6.8 & 1 & 2.6 & 1.8 & 2 & 6.5 & $30-40 \%$ & 0.15 & & \\
\hline
\end{tabular}


Confidential manuscript submitted to Tectonics

\begin{tabular}{|c|c|c|c|c|c|c|c|c|c|c|}
\hline $\mathrm{D}$ & 9 & 1 & 2.2 & 2 & 1 & 14 & $<30 \%$ & 0.27 & & \\
\hline $\mathrm{D}$ & 13.2 & 1.9 & 4.2 & 2.9 & 0 & & & 0.14 & $\mathrm{x}$ & \\
\hline $\mathrm{D}$ & 13.7 & 0.5 & 0.5 & 2.4 & 2 & 14.5 & & 0.42 & & \\
\hline $\mathrm{D}$ & 14.9 & 0.5 & 1.2 & 1 & 0 & & & 0.23 & & \\
\hline $\mathrm{D}$ & 16.6 & 0.7 & 1.7 & 1.2 & 2 & 15 & & 0.15 & & \\
\hline $\mathrm{D}$ & 18.2 & 0.9 & 1.6 & 1.6 & 1 & 12 & & 0.31 & $\mathrm{x}$ & \\
\hline $\mathrm{D}$ & 19.8 & 0.6 & 1.6 & 1.5 & 1 & 12 & & 0.26 & & \\
\hline $\mathrm{D}$ & 22.5 & 1.2 & 2.7 & 1.8 & 1 & 14 & & 0.16 & $\mathrm{x}$ & \\
\hline $\mathrm{D}$ & 26.5 & 1.7 & 4 & 2.9 & 2 & 10 & & 0.16 & & \\
\hline $\mathrm{E}$ & 3.8 & 1 & 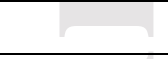 & & 10 & 13 & & & & \\
\hline $\mathrm{E}$ & 6.4 & 0.9 & 2.6 & 1.9 & 7 & 11.3 & $<30 \%$ & 0.17 & & \\
\hline$E$ & 8.3 & 0.6 & 1.9 & 1.5 & 4 & 13.8 & & 0.2 & & $\mathrm{x}$ \\
\hline $\mathrm{E}$ & 9.6 & 0.5 & 1.3 & 1.1 & 4 & 10.8 & & 0.24 & & $\mathrm{x}$ \\
\hline $\mathrm{E}$ & 11.4 & 0.7 & 1.8 & 1.2 & 6 & 13.3 & & 0.13 & $\mathrm{x}$ & $\mathrm{x}$ \\
\hline $\mathrm{E}$ & 14.4 & 1.5 & 3 & 2.2 & 3 & 11.7 & & 0.16 & $\mathrm{x}$ & $\mathrm{x}$ \\
\hline$E$ & 19.7 & 1.7 & 5.3 & 3.2 & 6 & 12.8 & & 0.1 & & $\mathrm{x}$ \\
\hline$E$ & 24 & 2.6 & 4.3 & 4.3 & 5 & 11.4 & & 0.31 & $\mathrm{x}$ & \\
\hline $\mathrm{F}$ & 4 & 0.5 & 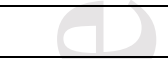 & & 1 & 9 & & & & \\
\hline $\mathrm{F}$ & 6.2 & 0.8 & 2.2 & 1.3 & 2 & 11.5 & $>40 \%$ & 0.09 & & \\
\hline$F$ & 11.1 & 1.5 & 4.9 & 2.3 & 3 & 10 & $<30 \%$ & 0.03 & & \\
\hline $\mathrm{F}$ & 19.6 & 3 & 8.5 & 4.5 & 1 & 13 & & 0.06 & & \\
\hline$G$ & 4.1 & 0.6 & $(0$ & & 2 & 9 & & & & \\
\hline $\mathrm{G}$ & 6 & 0.7 & 1.9 & 1.3 & 2 & 13.5 & $>40 \%$ & 0.14 & & \\
\hline $\mathrm{G}$ & 8 & 0.5 & 2 & 1.2 & 0 & & & 0.09 & & \\
\hline$G$ & 11.3 & 1.2 & 3.3 & 1.7 & 5 & 13.2 & $<30 \%$ & 0.05 & & \\
\hline $\mathrm{G}$ & 15.2 & 1.2 & 3.9 & 2.4 & 1 & 16 & & 0.1 & & \\
\hline $\mathrm{G}$ & 22 & 1.1 & 6.8 & 2.3 & 1 & 7 & & 0.003 & & \\
\hline
\end{tabular}


300 Table 3. COPD peaks extracted for the $2 \sigma$ model. Mean quality is computed on the set of individual measurements supporting each

301 peak. Spreading value is expressed in \% of the mean of measurements supporting the first two peaks per segment. The overlapping

302 coefficient is computed using normalized distributions.

303

304

305

306

307

308

309

310

311

312 
COPD peak values $(\mathrm{m})$

\begin{tabular}{|c|c|c|c|c|c|c|c|c|c|c|}
\hline & Peak 1 & Peak 2 & Peak 3 & Peak 4 & Peak 5 & Peak 1 & Peak 2 & Peak 3 & Peak 4 & Peak 5 \\
\hline$B$ & $\begin{array}{c}\mathbf{6 . 2 \pm 2} \\
(6.1 \pm 1.3)\end{array}$ & $11.2 \pm 1.0$ & $\begin{array}{c}\mathbf{1 8 . 1} \pm \mathbf{2 . 1} \\
(18.2 \pm 1.4)\end{array}$ & & & $\begin{array}{c}\mathbf{6 . 2 \pm 2} \\
(6.1 \pm 1.3)\end{array}$ & $5 \pm 3.0$ & $\begin{array}{c}\mathbf{6 . 9} \pm \mathbf{3 . 1} \\
(12.1 \pm 2.6)\end{array}$ & & \\
\hline $\mathrm{C}$ & $\begin{array}{c}\mathbf{4 . 1} \pm \mathbf{1 . 4} \\
(4.2 \pm 0.5)\end{array}$ & $\begin{array}{c}\mathbf{8 . 8} \pm \mathbf{1 . 7} \\
(9.0 \pm 0.8)\end{array}$ & & & & $\begin{array}{c}\mathbf{4 . 1} \pm \mathbf{1 . 4} \\
(4.2 \pm 0.5)\end{array}$ & $\begin{array}{c}\mathbf{4 . 7} \pm \mathbf{3 . 1} \\
(4.8 \pm 1.3)\end{array}$ & & & \\
\hline D & $\begin{array}{c}\mathbf{4 . 5} \pm \mathbf{1 . 7} \\
(5.5 \pm 1.8)\end{array}$ & $8.6 \pm 1.9$ & $\begin{array}{c}\mathbf{1 4 . 2} \pm \mathbf{1 . 5} \\
(13.7 \pm 0.5)\end{array}$ & $\begin{array}{c}\mathbf{1 8 . 2} \pm \mathbf{2 . 1} \\
(16.6 \pm 0.7)\end{array}$ & $\begin{array}{c}\mathbf{2 4 . 6} \pm \mathbf{3 . 3} \\
(26.5 \pm 1.7)\end{array}$ & $\begin{array}{c}\mathbf{4 . 5} \pm \mathbf{1 . 7} \\
(5.5 \pm 1.8)\end{array}$ & $4.1 \pm 3.6$ & $\begin{array}{c}\mathbf{5 . 6} \pm \mathbf{3 . 4} \\
(8.2 \pm 2.3)\end{array}$ & $\begin{array}{c}\mathbf{4 . 0} \mathbf{4} \pm \mathbf{3 . 6} \\
(2.9 \pm 1.2)\end{array}$ & $\begin{array}{c}\mathbf{6 . 4} \pm \mathbf{5 . 4} \\
(9.9 \pm 2.4)\end{array}$ \\
\hline $\mathrm{E}$ & $\begin{array}{c}\mathbf{4 . 2} \pm \mathbf{1 . 7} \\
(3.8 \pm 1.0)\end{array}$ & $\begin{array}{c}\mathbf{7 . 4} \pm \mathbf{1 . 0} \\
(6.4 \pm 0.9)\end{array}$ & $11.7 \pm 0.9$ & $22.3 \pm 2.1$ & & $\begin{array}{c}\mathbf{4 . 2} \pm \mathbf{1 . 7} \\
(3.8 \pm 1.0)\end{array}$ & $\begin{array}{c}\mathbf{3 . 2} \pm \mathbf{2 . 7} \\
(2.6 \pm 1.9)\end{array}$ & $4.3 \pm 1.9$ & $10.6 \pm 3.0$ & \\
\hline $\mathrm{F}$ & $\begin{array}{c}\mathbf{5 . 9} \pm \mathbf{1 . 8} \\
(5.1 \pm 1.3)\end{array}$ & $\begin{array}{c}\mathbf{1 1 . 6} \pm \mathbf{2 . 2} \\
(11.1 \pm 1.5)\end{array}$ & & & & $\begin{array}{c}\mathbf{5 . 9} \pm \mathbf{1 . 8} \\
(5.1 \pm 1.3)\end{array}$ & $\begin{array}{c}\mathbf{5 . 7} \pm \mathbf{4 . 0} \\
(6.0 \pm 2.8)\end{array}$ & & & \\
\hline G & $\begin{array}{c}\mathbf{5 . 9} \pm \mathbf{1 . 5} \\
(5.1 \pm 1.3)\end{array}$ & $\begin{array}{c}\mathbf{1 1 . 3} \pm \mathbf{1 . 6} \\
(11.3 \pm 1.2)\end{array}$ & & & & $\begin{array}{c}\mathbf{5 . 9} \pm \mathbf{1 . 5} \\
(5.1 \pm 1.3)\end{array}$ & $\begin{array}{c}\mathbf{5 . 4} \pm \mathbf{3 . 1} \\
(6.2 \pm 2.5)\end{array}$ & & & \\
\hline
\end{tabular}

Table 4. Best constrained cumulative offsets and slip increments computed for each fault segment in the offset range 0-30 $\mathrm{m}$. The

317 Uncertainties are $1 \sigma$. Bold values are from the $1 \sigma$ model. Values in brackets are those deduced from the $2 \sigma$ model. We underline

318 values showing consistency between the two models. 
3196 Terrace dating

\begin{tabular}{|c|c|c|c|c|c|c|c|c|}
\hline Terrace & Sample code & Depth $(\mathrm{cm})$ & $\begin{array}{l}\text { Dissolved } \\
\text { quartz } \\
\text { mass }(\mathrm{g}) \\
\end{array}$ & $\begin{array}{l}{ }^{9} \mathrm{Be} \text { carrier } \\
\text { solution }(\mathrm{g})\end{array}$ & $\begin{array}{c}{ }^{10} \mathrm{Be} /{ }^{9} \mathrm{Be} \text { ratio } \pm 1 \sigma \mathrm{AMS} \\
\text { uncertainty }\left(10^{-15} \text { blank }\right. \\
\text { corrected })\end{array}$ & $\begin{array}{c}{ }^{10} \mathrm{Be}\left(10^{4}\right. \\
\text { at/g) }\end{array}$ & $\begin{array}{l}\stackrel{{ }^{10} \mathrm{Be}}{\text { concentration }} \\
\text { uncertainty }(\%)\end{array}$ & Sampling site location \\
\hline T3 & 15TUR5-0a & 0 & 17.179 & 0.2988 & $9.913 \pm 1.208$ & 1.1499 & 23.05 & $40.3974^{\circ} \mathrm{N}-29.6966^{\circ} \mathrm{E}$ \\
\hline $\mathrm{T} 3$ & 15TUR5-0b & 0 & 18.480 & 0.2990 & $23.17 \pm 6.328$ & 2.5003 & 34.99 & $94 \pm 4 \mathrm{~m}$ asl \\
\hline $\mathrm{T} 3$ & 15TUR5-20 & $20-35$ & 2.864 & 0.3010 & $3.428 \pm 0.744$ & 2.4060 & 69.82 & $\mathrm{TS}=0.997$ \\
\hline $\mathrm{T} 3$ & 15TUR5-60 & $60-70$ & 10.739 & 0.2995 & $8.012 \pm 0.956$ & 1.4902 & 25.69 & \\
\hline $\mathrm{T} 3$ & 15TUR5-80 & $80-90$ & 16.347 & 0.2980 & $12.25 \pm 1.234$ & 1.4896 & 17.91 & \\
\hline $\mathrm{T} 3$ & 15TUR5-130 & $130-140$ & 6.789 & 0.2976 & $3.808 \pm 0.556$ & 1.1132 & 49.12 & \\
\hline $\mathrm{T} 2$ & 15TUR3-0b & 0 & 18.510 & 0.3078 & $89.09 \pm 5.310$ & 9.8809 & 6.52 & $127 \pm 3 \mathrm{~m}$ asl \\
\hline $\mathrm{T} 2$ & 15TUR3-60 & $60-85$ & 20.824 & 0.2989 & $53.09 \pm 4.953$ & 5.0837 & 10.65 & $\mathrm{TS} \sim 1$ \\
\hline $\mathrm{T} 2$ & 15TUR3-110 & $110-130$ & 19.941 & 0.2905 & $245.1 \pm 8.848$ & 23.8183 & 3.75 & \\
\hline $\mathrm{T} 2$ & 15TUR3-150 & $150-175$ & 17.038 & 0.2993 & $200.4 \pm 32.61$ & 23.4781 & 16.79 & \\
\hline $\mathrm{T} 1$ & 15TUR4-0a & 0 & 20.838 & 0.2979 & $226.9 \pm 75.69$ & 21.6293 & 34.27 & $40.5031^{\circ} \mathrm{N}-29.6860^{\circ} \mathrm{E}$ \\
\hline $\mathrm{T} 1$ & 15TUR4-0b & 0 & 20.514 & 0.2973 & $313.7 \pm 11.86$ & 30.3225 & 3.89 & $164 \pm 3 \mathrm{~m}$ asl \\
\hline $\mathrm{T} 1$ & 15TUR4-30 & $30-40$ & 20.550 & 0.2958 & $255.4 \pm 7.943$ & 24.5165 & 3.24 & $\mathrm{TS} \sim 1$ \\
\hline $\mathrm{T} 1$ & 15TUR4-80 & $80-90$ & 23.547 & 0.2981 & $292.6 \pm 11.47$ & 24.7008 & 4.03 & \\
\hline $\mathrm{T} 1$ & 15TUR4-260 & $260-270$ & 22.204 & 0.2966 & $184.8 \pm 9.776$ & 16.4640 & 5.52 & \\
\hline $\mathrm{T} 1$ & 15TUR4-370 & $370-380$ & 20.771 & 0.2980 & $243.5 \pm 12.71$ & 23.2995 & 5.38 & \\
\hline
\end{tabular}

321 Table 5. Characteristics of the terrace samples and results of the nuclide measurements. The ${ }^{10} \mathrm{Be} /{ }^{9} \mathrm{Be}$ ratio of the blank is $6.200 .10^{-15}$

322 with an analytical uncertainty of $19 \%$. TS is topographic shielding value. The total measurement error includes the uncertainties

323 associated with the AMS measurement, the blank value, the dissolved quartz mass and the spike mass weighing and concentration. 


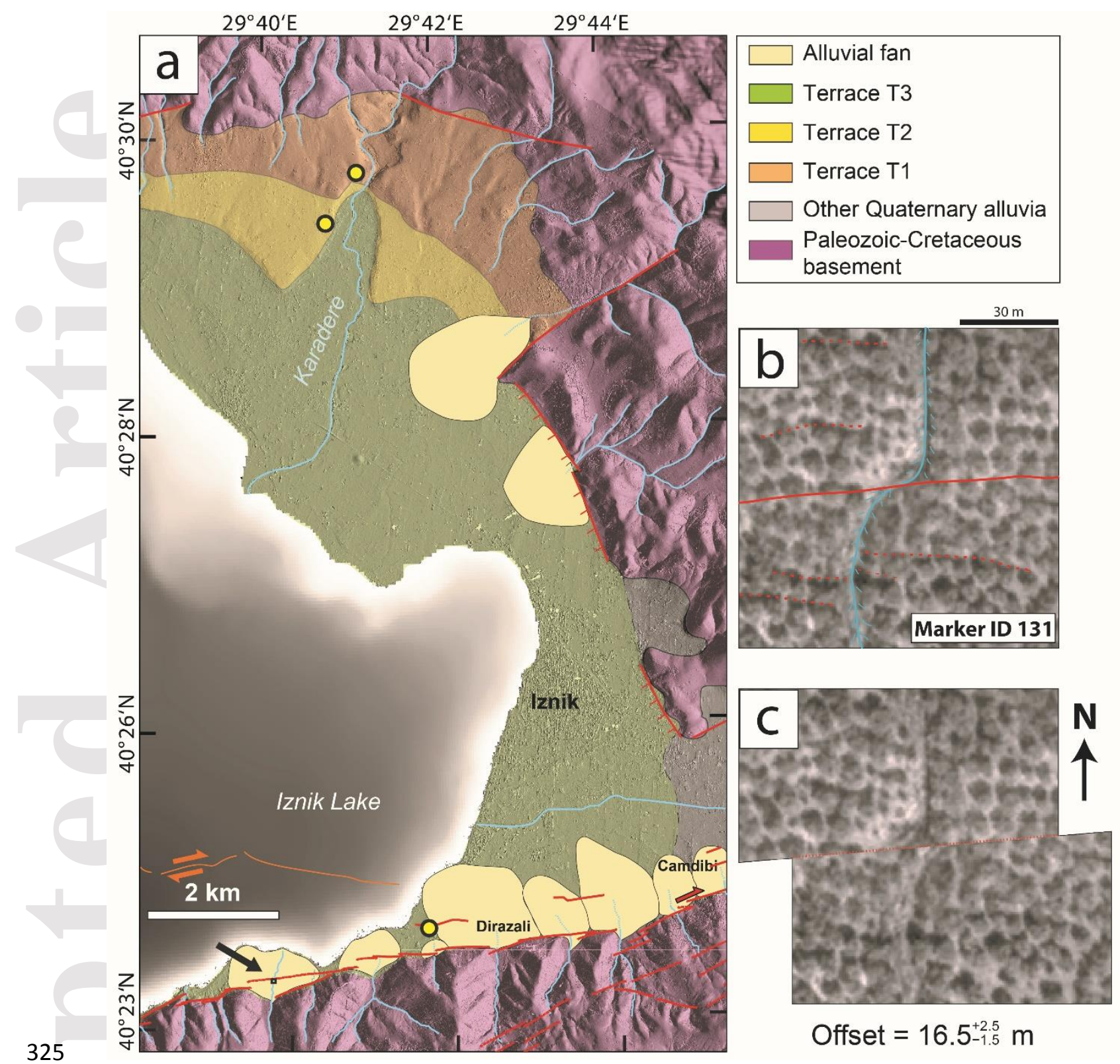

326 Figure 9. (a) General location of the terrace sampled for cosmogenic dating (yellow dots).

327 Active faults are mapped in red-orange and main streams are drawn in blue. The subaqueous

328 fault trace is taken from Gastineau et al. (2021). The eastern limit of terrace T3 is not well

329 defined in the geomorphology and was drawn assuming a constant elevation. The marker used to

330 derive a minimum horizontal slip rate is indicated with a black arrow. (b) Interpreted Pleiades

331 image of the present-day marker morphology. (c) Preferred retro-deformed morphology.

This article is protected by copyright. All rights reserved. 


\section{Schematic log Lithological description}
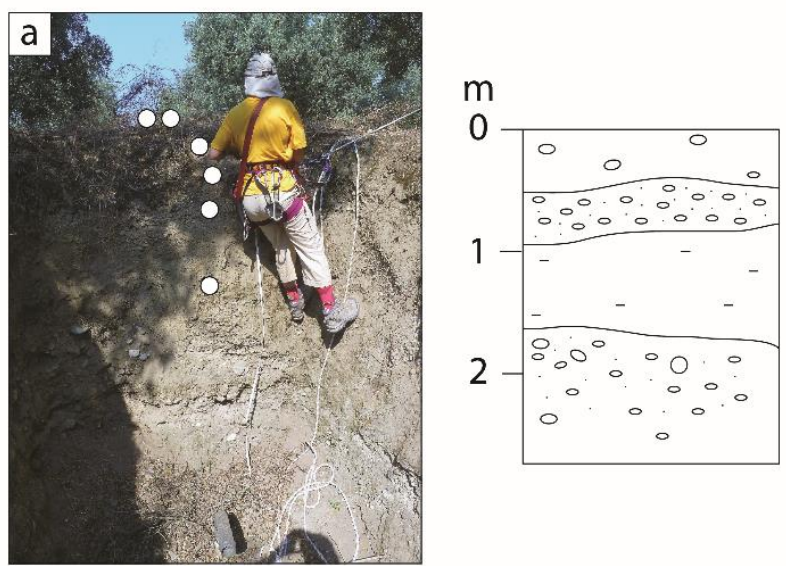

hard, dark brown soil with few, centimetric pebbles

light brown, sandy layer, numerous pebbles

brownish grey clay layer

coarse silt layer, heterogeneous unsorted pebbles

$\mathrm{T} 2$

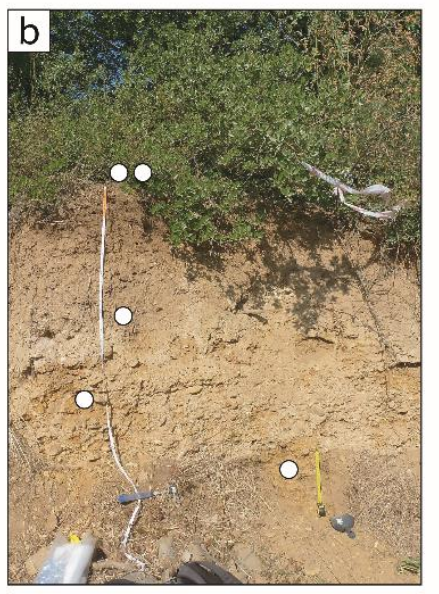

$$
\mathrm{m}
$$

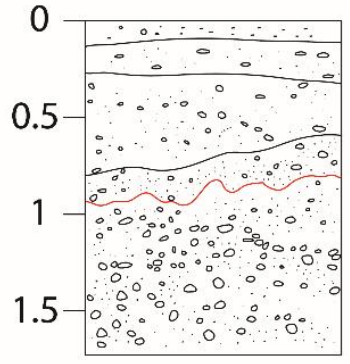

thin brown soil with few gravel dark brown silty layer with few pebbles

brown sandy layer, homogeneous rounded pebbles

light brown, gravel-rich sandy layer with few pebbles

coarse, orange sandy layer, abundant pebbles and gravel

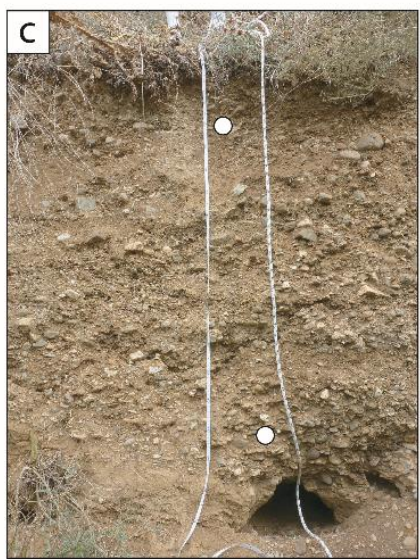

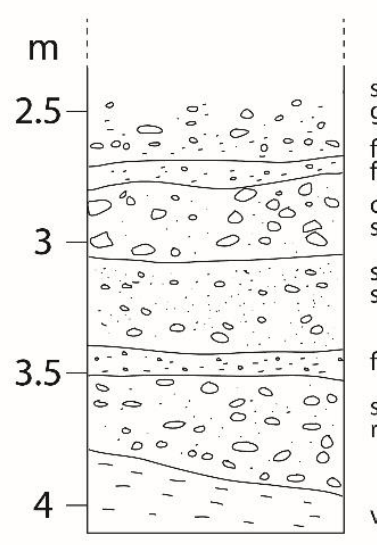

sandy layer, gravel and heterogeneous pebbles

fine sandy layer with gravel and few pebble

coarse sandy layer with large,

subrounded pebbles

sandy layer with abundant small pebbles

fine, gravel-rich sandy layer

sandy layer, homogeneous rounded pebbles

very fine silty-sandy layer

333 Figure 10. Field photographs (left) and interpreted stratigraphy (right) of the terrace profiles

334 sampled for dating, T3 (a), T2 (b), and T1 (c). The samples are represented with white circles.

335 The first meters of T1 profile were covered with bushes, and consisted of a homogeneous brown,

336 silty-sandy unit with a few centimetric pebbles.

This article is protected by copyright. All rights reserved. 
337 Actually, the statistical analysis of cumulative offsets evidences the occurrence of past ruptures

338 along the MNAF and documents the associated slip-per-event, but does not inform the age of

339 these events. To narrow down the age range for the identified events and estimate the late

340 Quaternary slip rate of the MNAF, we need constraints on the age of the terranes that were offset

341 by the fault. The area surrounding Iznik Lake displays low gradient alluvial fans emplaced on

342 three preceding levels of abandoned lake plains, which were targeted in this study. These flat

343 levels, separated by wave-cut scarps, have been known and interpreted as lacustrine terraces

344 since the early 20th century (Chaput, 1936; Tanoglu and Erinc, 1956). They appear particularly

345 well-developed north and east of Iznik Lake (Ikeda et al., 1991; Fig. 9a). The terraces were

346 presumably deposited originally with a small slope, but the current slope tends to increase with

347 elevation and age, and also in the central part as the terraces get closer to the mountain range.

348 The lowest scarp associated with the youngest lake plain (Tl3) is the clearest and can be traced

349 almost over the entire length of the northern coast. The height of its inner edge above the present

350 lake level (a.1.1.) is about 20 meters northwest Boyalica village. The intermediate terraceT2 can

351 also be easily traced in the west but is hardly visible in the central part around Boyalica. The

352 associated wave-cut scarp appears again in the wider alluvial plain northeast of the lake, with an

353 inner edge $60 \mathrm{~m}$ high a.1.1. The highest and oldest terraceT1 is much more degraded but can still

354 be traced almost continuously in the west with a $110 \mathrm{~m}$ a.l.l. high inner edge. Remnants of this

355 old paleoshoreline and the associated sediments can be observed in the northeast, especially

356 along an irrigation canal constructed west of the Karadere stream. In the southern part, these

357 successive terrace levels cannot be unambiguously mapped and have been partly overlain by

358 younger alluvial sediments, especially in areas where the lake shore comes very near to the foot

359 of the mountain front.

This article is protected by copyright. All rights reserved. 


\subsection{Sampling and analytical method}

361 To date the terraces, we used the in-situ produced terrestrial cosmogenic nuclide (TCN) method.

362 The terraces were sampled along vertical profiles (Fig. 10, Table 5). For terraces T1 and T2,

363 samples were taken on pre-existing, man-made scarps. These scarps have been laterally refreshed

364 due the surrounding agricultural activity, preventing a significant nuclide accumulation from

365 posterior lateral exposure. For terrace T3, we benefited from a pit dug in the plain for

366 hydrological maintenance. The pit is located close to the western edge of the major fan of

367 Dirazali, so an alluvial contribution posterior to the emersion of the lake plain cannot be ruled

368 out. The outcrops displayed alternations of fine sand and coarser gravel-rich conglomerate with

369 graded bedding, with no evidence of buried paleosols. T1 and T3 mainly showed alluvial facies,

370 the former displaying evidence of paleochannels and cross-stratification. T2 showed lateral

371 facies variations, with finer, lacustrine deposits on the north-central shore of the lake, and coarser

372 fluvial deposits in the east at the sampling site. While T1 and T3 profiles can be assumed to

373 represent a continuous sedimentation sequence, T2 profile displays an irregular interface at $1 \mathrm{~m}$

374 depth that suggests an interruption in the sedimentation process potentially associated with

375 emersion and erosion (red line on Fig. 10b). For each profile, we collected two samples on the

376 surface of the terrace, and when possible, three to four samples in the first $1.5 \mathrm{~m}$ below the

377 surface, and one to two deeper samples at the bottom of the profile to constrain the potential

378 inherited nuclide content. We sampled pebbles made of silicate material in order to have $\sim 100 \mathrm{~g}$

379 of quartz per sample.

380 The beryllium was extracted at the Geo-thermo-chronology platform (ISTerre, University

381 Grenoble Alpes, France). Quartz was obtained from the 250-500 $\mu \mathrm{m}$ fraction after isolation of

382 the non-magnetic grains by repeated leaching in $\mathrm{H}_{2} \mathrm{SiF}_{6}-\mathrm{HCl}$ mixture. The samples were then

This article is protected by copyright. All rights reserved. 
383 processed following the chemical procedure of Brown et al. (1991) and Merchel and Herpers

384 (1999). The beryllium was finally measured as a ${ }^{10} \mathrm{Be} /{ }^{9} \mathrm{Be}$ ratio at the ASTER Accelerator Mass

385 Spectrometer in Aix-en-Provence, France (Arnold et al., 2010).

\section{$386 \quad 6.2$ Age determination}

387 The obtained concentration-depth-profiles (Table 5 and Fig. 11, 12, 13) were modelled with a

388 Monte Carlo approach using the code ${ }^{10}$ Be profile simulator version 1.2 developed by Hidy et al.

389 (2010). This approach enables to find the combination of parameters that best fits the measured

390 profile, including the exposure age, the erosion rate and the inherited TCN concentration. The

391 validity of the method requires the following conditions: the TCN concentrations have not

392 reached equilibrium with the landscape, the sampled profile corresponds to a unique episode of

393 deposition and exposure with no vertical mixing, the inherited concentration is constant over the

394 sampled depth range.

395 The halflife of ${ }^{10} \mathrm{Be}(1.387 \pm 0.012 \mathrm{Ma})$ was taken from Chmeleff et al. (2010). We used a global 396 mean SLHL (sea level and high latitude ) reference production rate of $4.06 \pm 0.23$ atoms.g $\mathrm{g}^{-1} \cdot \mathrm{a}^{-1}$ for

397 the neutron induced spallogenic production using the CREp program (Martin et al., 2017), with 398 the Lifton-Sato-Dunai scaling scheme (Lifton et al., 2014), the ERA40 atmosphere model

399 (Uppala et al., 2005), and the Lifton VDM 2016 geomagnetic correction (Lifton, 2016). The

400 muonic production was calculated using the theoretical equations of Heisinger et al. (2002a,b)

401 and determined at the sampling site's elevation and for a given depth following the approach of

402 Balco et al. (2008). The depth of muonic production fit was set at $5 \mathrm{~cm}$. The error in $10 \mathrm{Be}$ half-

403 life was set at 5\%. The sampling sites were not associated with significant topographic/geometric

404 shielding or additional cover. The cumulative bulk density of the material above each sample

This article is protected by copyright. All rights reserved. 
405 was assumed constant over depth, with an average value of $2.2 \mathrm{~g} / \mathrm{cm}^{3}$, previously measured in 406 similar gravel-based terraces (Hidy et al., 2010). For the first iterations, the initial parameters for 407 age, inheritance and erosion rate were allowed to vary largely (age between 5-40 ka, erosion rate 408 below $3 \mathrm{~cm} / \mathrm{ka}$, and inheritance below $25.105 \mathrm{at} / \mathrm{g}$ ). The total erosion threshold was set between $409 \quad 0$ and $30 \mathrm{~cm}$.
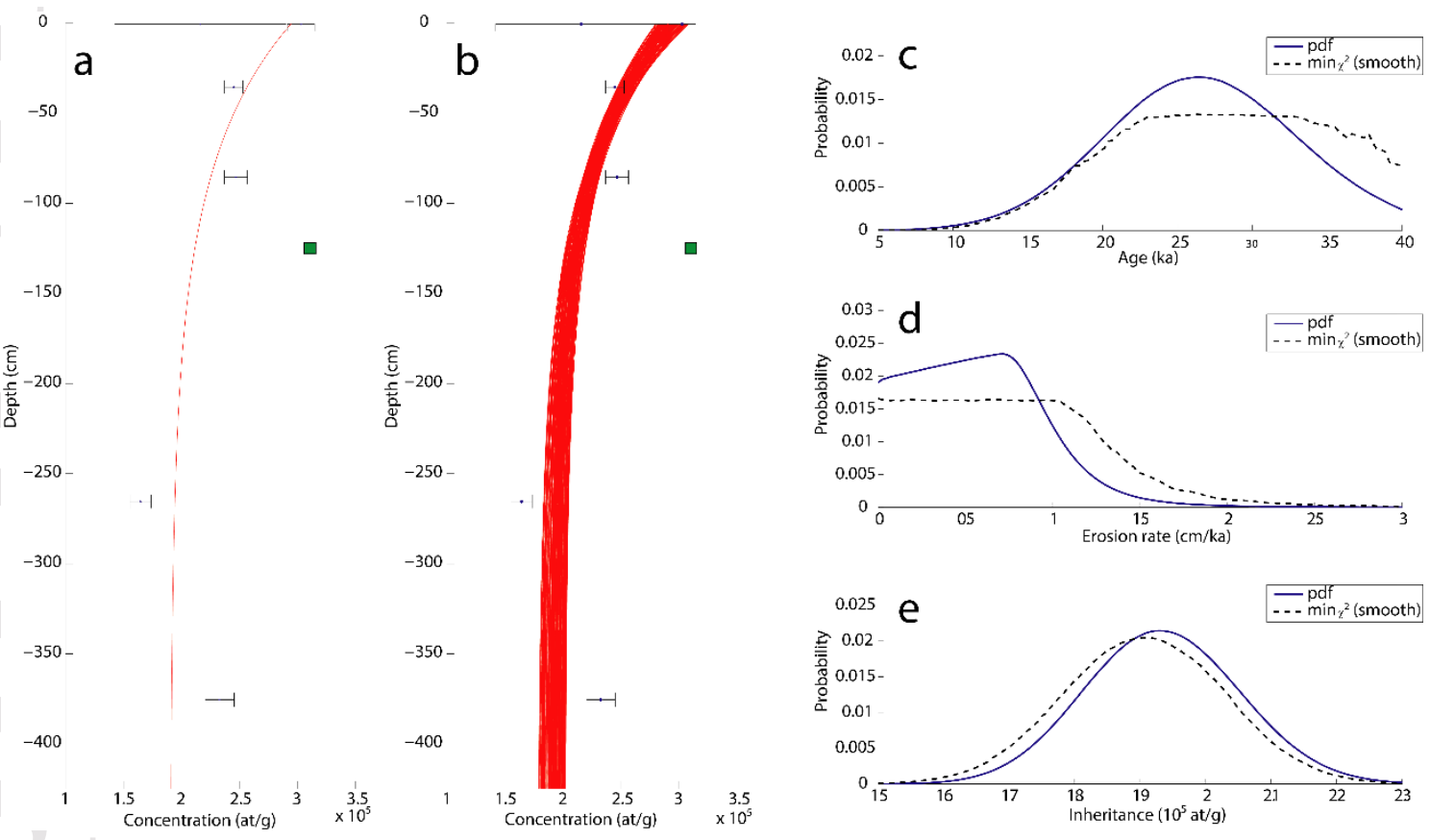

412 Figure 11. Result of the Monte Carlo simulations for terrace T1. (a) ${ }^{10} \mathrm{Be}$ concentrations

413 measured along depth and best fit obtained. (b) All the solutions found in the parameter solution 414 space defined as inputs. The sample excluded from the inversion is shown as a green box. (c, d, 415 e) Probability density functions (solid lines) and minimum $\chi^{2}$ distributions (dashed line) for the 416 exposure age, erosion rate and inheritance concentration respectively. 
418 Terrace T1 profile presents one point (15TUR4-130) with a high concentration, larger than the 419 surface samples, which is incompatible with the theoretical depth profile. After excluding this 420 sample, the algorithm was not able to find solutions in the $2 \sigma$ confidence windows, and we had 421 to increase the $\chi^{2}$ cut-off value to 11 . Although doing so prevented us from properly quantifying 422 the error on the parameters, the best fits among the 250,000 solutions obtained provided a modal 423 age of $27.0_{-13.0}^{+10.9}{ }^{10} \mathrm{Be} \mathrm{ka} \mathrm{BP}$ (Fig. 11), a low erosion rate ranging below $1 \mathrm{~cm} / \mathrm{ka}$, and a much 424 higher inheritance around $\sim 190,000 \mathrm{at} / \mathrm{g}$.

\section{5}
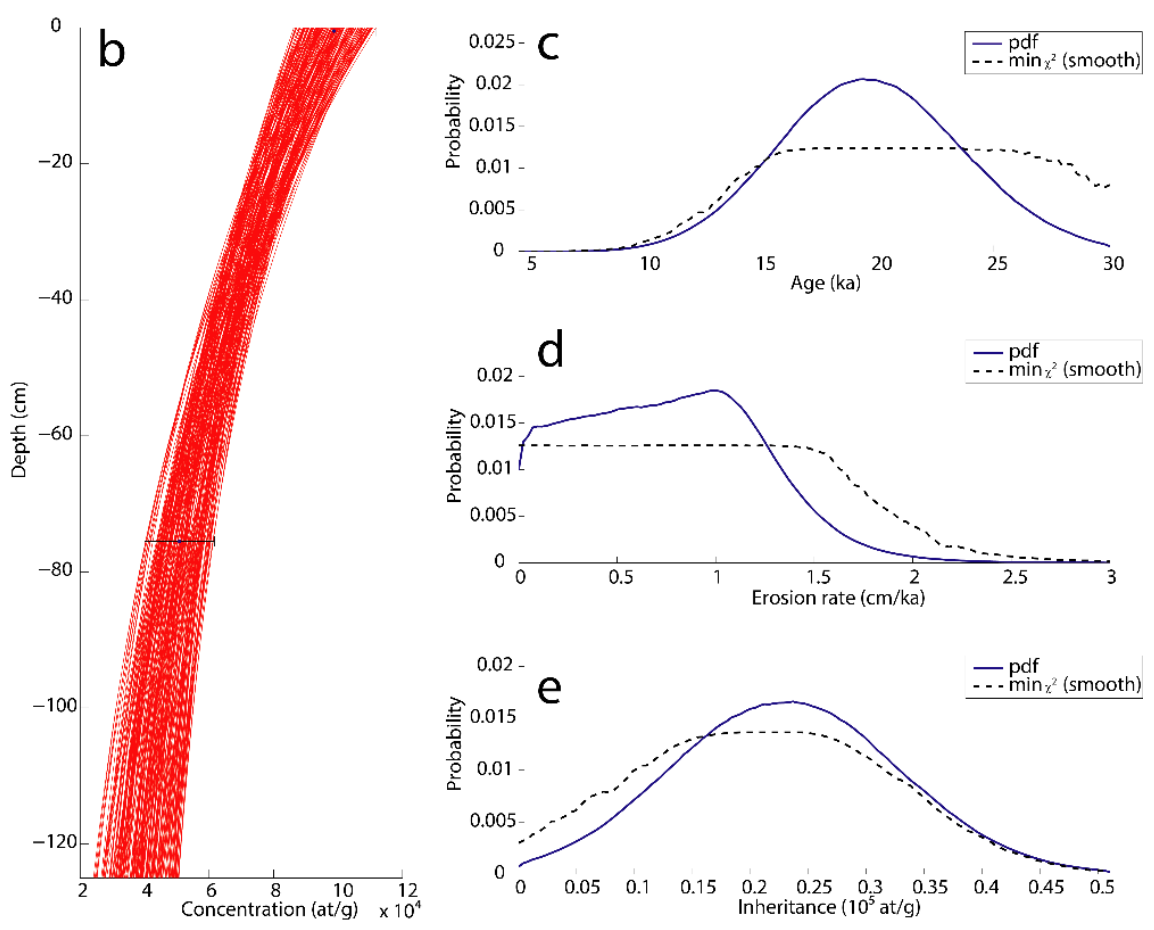

427 Figure 12. Result of the Monte Carlo simulations for terrace T2. (a) ${ }^{10} \mathrm{Be}$ concentrations

428 measured along depth and best fit obtained. (b) All the solutions found in the parameter solution

429 space defined as inputs. The three samples excluded from the inversion show concentrations

430 above 120,000 at/g. (c, d, e) Probability density functions (solid lines) and minimum $\chi^{2}$ 
431 distributions (dashed line) for the exposure age, erosion rate and inheritance concentration 432 respectively.

433 Terrace T2 profile presents more complexity, especially because the two deepest samples 434 (15TUR3-110 and 15TUR3-150) have the highest nuclide concentrations of all the dataset. As 435 the outcrop stratigraphy suggests, they are likely to belong to a previous deposition sequence

436 which was eroded before the onset of a new sedimentation sequence over it. The algorithm could 437 only converge towards a solution after excluding these deep samples, and one surface sample 438 (15TUR3-0a) showing a low nuclide concentration. With only two samples, it is impossible to 439 determine statistically robust solutions for the age, erosion rate and inheritance at the same time.

440 To narrow down the solution space, we constrained the initial inheritance using the concentration 441 of sample 15TUR3-60 as upper bound, and the initial age below the age obtained for T1. We 442 finally obtained 250,000 solutions within the $2 \sigma$ confidence window, giving a most probable age 443 of 19. -7.2 $_{-7.7}^{10} \mathrm{Be} \mathrm{ka} \mathrm{BP} \mathrm{(Fig.} \mathrm{12).}$

444 For terrace T3, the simulator was not able to produce solutions when all the data of the profile 445 were included, especially because one surface sample (15TUR5-0a) showed a very low 446 concentration comparable to the deepest sample (15TUR5-130). We assumed this sample to be 447 an outlier, likely to originate from recent excavation and deposition during agricultural work. We 448 observed that the profile data did not permit to constrain the erosion rate. We tested initial 449 maximum erosion rates of 1,2 and $3 \mathrm{~cm} / \mathrm{kyr}$ and obtained similar results between the three 450 simulations. Using a moderate erosion rate of $1 \mathrm{~cm} / \mathrm{kyr}$ as initial upper bound, the 250,000 451 solutions found within the $2 \sigma$ confidence window gave a most probable age of $3.8_{-2.7}^{+6.3}{ }^{10} \mathrm{Be} \mathrm{ka}$ 452 BP. This involves an inheritance of $\sim 8000$ at/g (i.e. $30 \%$ of the surface sample) (Fig. 13e). 453 Finally, we considered the possibility that additional exposure may happen under a shallow lake 
454 water cover, which would lead to an overestimation of the age of subaerial exposure, as TCN

455 started to accumulate before the total emersion and abandonment of the lake plain. A water depth 456 of $4 \mathrm{~m}$ allows $\sim 10 \%$ of the influx of cosmic rays to hit the sediments. To estimate the amplitude 457 of this effect on the final age, we ran the simulation with the nuclide concentrations decreased by $45810 \%$. This correction resulted in a $16 \%$ younger age, which suggests that this effect remains 459 small relative to the $2 \sigma$ uncertainty range.
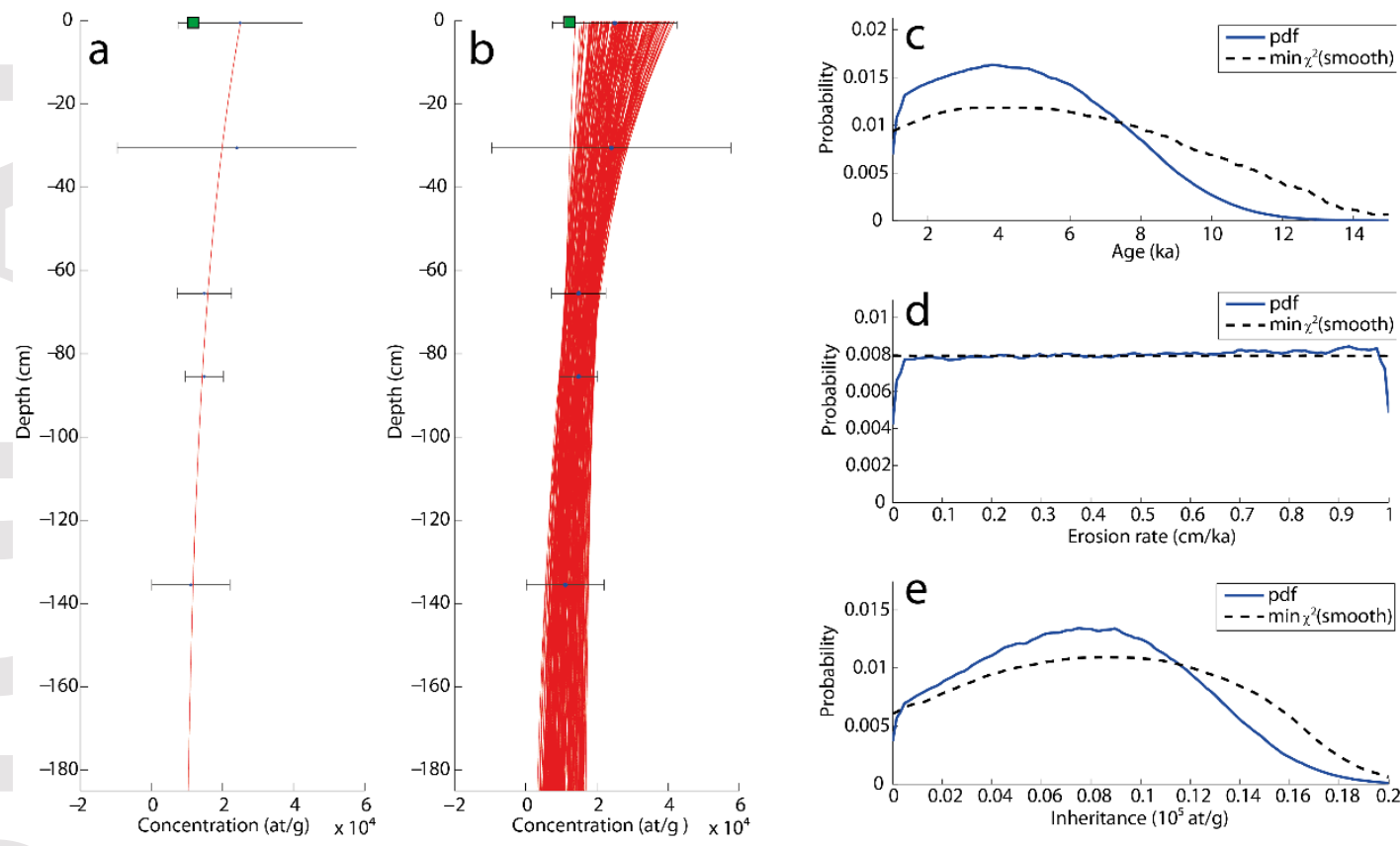

461 Figure 13. Result of the Monte Carlo simulations for terrace T3. (a) ${ }^{10}$ Be concentrations

462 measured along depth and best fit obtained. (b) All the solutions found in the parameter solution 463 space defined as inputs. The sample excluded from the inversion is shown as a green box. (c, d, 464 e) Probability density functions (solid lines) and minimum $\chi^{2}$ distributions (dashed line) for the 465 exposure age, erosion rate and inheritance concentration respectively. 


\section{Discussion}

\section{$468 \quad 7.1$ Horizontal slip rate estimate}

469 Horizontal slip rates are usually constrained by dating sedimentary units laterally displaced by

470 the faults (Hubert-Ferrari et al., 2002; Kozaci et al., 2007, 2009; Le Béon et al., 2010; Rizza et

471 al., 2011; van der Woerd et al., 2006; Zabci et al., 2015). This kind of estimation is preferentially

472 done with cumulative offsets of several hundreds of meters in order to average out the variability

473 of individual coseismic displacements (see e.g. Wechsler et al., 2018). This type of measurement

474 will yield a minimum slip rate as the offset is considered to be as old as the emplacement of the

475 sediments, although it could also be much younger without a way for us to know about it.

476 Southeast of the lake, the MNAF segments have displaced Holocene streams incising in the low-

477 gradient alluvial fans overlying terrace T3. Among the markers identified, the largest quality 1

478 offset measured is $\mathbf{1 6 . 5 _ { - 1 . 5 } ^ { + 2 . 5 }} \mathrm{m}$ on a river located $\sim 3.5 \mathrm{~km}$ west of Dirazali village (Fig. 9). The

479 COPD results suggest that this corresponds to the cumulative slip of the last 3 to 4 large

480 earthquakes. Deriving a slip-rate from this offset and our age of $\mathbf{3 . 8}_{-2.7}^{+6.3}{ }^{10} \mathrm{Be}$ ka BP for T3 is

481 hampered by two limitations. (i) The displaced stream may be significantly younger than the

482 underlying lake plain, so the ratio between the mean offset and the age of $\mathrm{T} 3$ can only provide a

483 minimum horizontal slip rate. (ii) The possible alluvial contribution at the sampling pit from the

484 Dirazali fan must be assumed synchronous or older than the fan incised in by the offset stream.

485 To propagate the $2 \sigma$ asymmetric uncertainties in the slip rate calculation, we used the NIST

486 Uncertainty Machine (https://uncertainty.nist.gov/; Lafarge and Possolo, 2016) with a Monte

487 Carlo approach. We obtained a horizontal slip rate of $\mathbf{4 . ~}_{-\mathbf{2 . 8}}^{+\mathbf{1 0 . 6}} \mathrm{mm} / \mathrm{yr}$. Although this value is in 488 the same range as the rate of $3.7 \pm 0.7 \mathrm{~mm} / \mathrm{yr}$ estimated by Gasperini et al. (2011) on Gemlik 
segment, it is poorly constrained due to the young age and large relative uncertainty of T3.

490

\section{$491 \quad 7.2$ Past seismic events evidenced along-strike}

492 Our study of cumulative offsets along the MNAF provides valuable information on earthquake

493 propagation along this fault, in terms of rupture extent, slip amount and distribution. It also

494 allows us to discuss the behavior of the MNAF segments during the last major earthquakes.

495 If we assume the first two peaks to be the signature of the last two large earthquakes, with

496 respective maximum coseismic slips of $6.2 \pm 2 \mathrm{~m}$ and $5.7 \pm 4 \mathrm{~m}$, empirical scaling laws suggest

497 that they correspond to events of moment magnitude of $7.2 \pm 0.2$ to $7.4 \pm 0.2$, with rupture lengths

498 of $73 \pm 28$ to $97 \pm 42 \mathrm{~km}$ (Wells \& Coppersmith, 1994; using all-slip-type and strike-slip

499 regressions respectively). Conversely, a rupture extending along the entirety of the $148 \mathrm{~km}$ long

500 studies section would correspond to an earthquake of moment magnitude $7.6 \pm 0.3$ and maximum

501 coseismic displacements of 6.7-6.8 m, using the same scaling relationships. Our results are

502 therefore compatible with large earthquakes able to rupture large parts of the eastern MNAF.

503 Wesnousky (2006) has suggested that there exists a maximal step-over size (3-4 km fault-

504 perpendicular) which tends to stop rupture propagation. However, this threshold has been

505 crossed in recent examples (e.g. Fletcher et al., 2014; Hamling et al., 2017). In our case, Sölöz

506 bend and Mekece, which are the largest identified step-overs of the eastern MNAF, have widths

507 of 2.5 and $1.5 \mathrm{~km}$ respectively, and it can thus be assumed that past large ruptures may have

508 propagated through them.

509 Our results show significant along-strike variability of the total number of recorded slip events

This article is protected by copyright. All rights reserved. 
510 and the associated slip values. Mean slip values tend to be lower for segments C, D and E. We

511 also note that segments D and E document more individual slip events than the other segments. It

512 has been observed that the COPD curve shows an exponential decay in the peaks' amplitude

513 with increasing cumulative slip (Klinger et al., 2011), as older markers tend to be less preserved

514 in the landscape. We find this kind of pattern for some segments (e.g. segment C), but for

515 segments $\mathrm{B}$ and $\mathrm{G}$ we observe that peak 1 is smaller than peak 2 . The central segments are

516 characterized by higher slopes. This implies more dynamic hydrologic conditions and

517 geomorphic marker formation, and thus a higher capacity to preserve the traces of successive

518 earthquakes (Zielke et al., 2015). By contrast, the lower slopes of the other segments may have

519 favored more intensive agricultural activities, thus partly erasing traces of past ruptures.

520 Therefore, a first possibility to explain the along-strike slip-per-event variability is to assume that

521 COPD peak 1 on segments B, F and $\mathrm{G}$ is cumulative, and that the last event was not preserved

522 enough on segments B, F and G to produce a strong COPD peak (Fig. 14b).

523 Alternatively, the slip decrease observed in the central segments may be related to their higher

524 geometrical complexity (fault bends and obliquity, overlapping segments and branching, see

525 sections 2 and 4.2). Distribution of the deformation across several structures implies that only

526 part of the slip can be measured on the investigated MNAF strand, leading to apparent local slip

527 decrease. A more oblique slip vector with a larger, unaccounted for vertical component,

528 especially along segments C and D, may have a similar effect. Lower horizontal coseismic slip

529 values along these segments may also suggest partial partitioning, with the subaqueous Iznik

530 fault accommodating a part of the horizontal displacement (see e.g. de Michele et al., 2010; King

531 et al., 2005 for recent examples of this). Finally, structural complexities may act as a barrier for

532 the propagation of ruptures, leading to smaller offsets through slip tapering (King and Nabelek,

This article is protected by copyright. All rights reserved. 
533 1985; Ward, 1997; Zielke et al., 2015).

This article is protected by copyright. All rights reserved. 

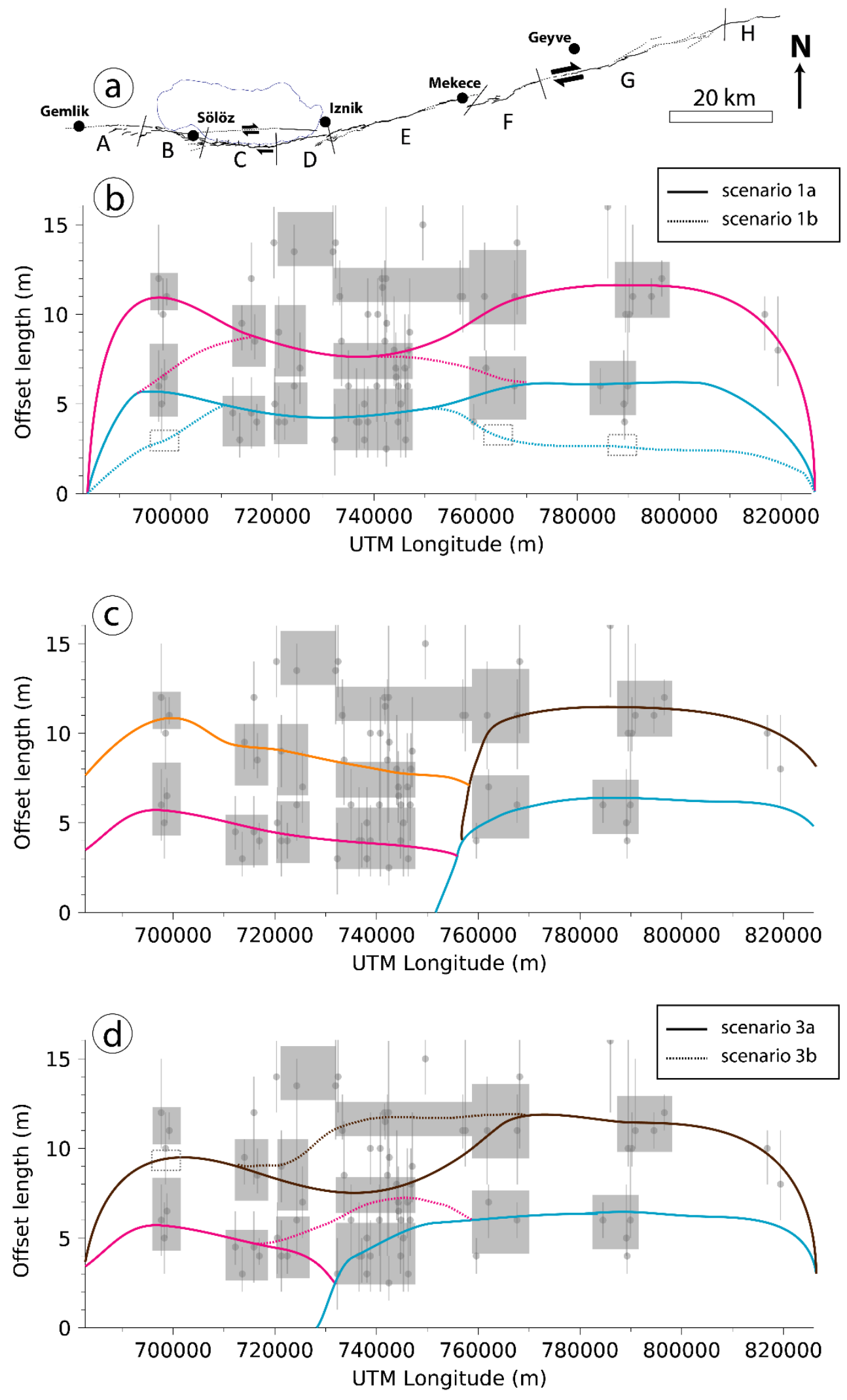

This article is protected by copyright. All rights reserved. 
535 Figure 14. (a) Geometry of the fault section studied. (b) First order scenarios of horizontal slip

536 distribution during past events. The last major event (light blue) is assumed to have ruptured all

537 the segments. The penultimate (magenta) replicates this slip distribution. Alternative scenario $1 \mathrm{~b}$

538 assumes a partly unpreserved, smaller slip (broken boxes) for the last major rupture. (c) Scenario

5392 of horizontal slip distribution. The last rupture is assumed to have propagated in the east of the

540 section studied and along segments $\mathrm{F}$ to $\mathrm{H}$. The penultimate event propagated along the

541 remaining segments and further west. The previous events (brown and orange) replicate these

542 slip distributions. (d) Scenario 3 of horizontal slip distribution. The last ruptures propagated

543 partially along the MNAF and neighboring systems. The antepenultimate event (brown) was a

544 full MNAF rupture with a partly unpreserved smaller slip on segment A. Alternative scenario $3 \mathrm{~b}$

545 assumes overlapping traces for the last ruptures on segment D.

547 The combination of the coseismic slip variation along strike, the epistemic uncertainty affecting

548 offset measurements and the evolution of markers' morphology since the last event can limit the

549 interpretation of COPD peaks as representing individual earthquakes (Lin et al., 2020; Reitman

550 et al., 2019). Given that the last large earthquake along the MNAF happened before the $20^{\text {th }}$

551 century and was not accurately documented at the time, we ignore the typical range of variation

552 for the coseismic slip. The surface slip during 1999 Düzce and Izmit earthquakes on the NNAF

553 show coefficients of variation (CoV) of 0.5-0.6 (Akyüz et al., 2002; Barka et al., 2002). Such

554 values of CoV hardly enable to confidently recover more than one or two events or sequence of

555 events from the COPD curve and estimate the associated slip values. Therefore, higher COPD

556 peak values and increments, which come with higher uncertainty, should be considered with

557 caution. A couple of slip increments on segments B and E exceed $6.5 \mathrm{~m}$ (Table 4) and seem less

This article is protected by copyright. All rights reserved. 
558 realistic given the magnitudes typically observed for recent earthquakes and estimated for

559 historical earthquakes in the Marmara region. Thus, we interpret those as being cumulative 560 contributions of two or more smaller, distinct events.

561 The slip history per segment resulting from our offset analysis does not unambiguously unravel

562 the past earthquakes succession along the MNAF. Alternative scenarios, with different numbers

563 of earthquakes, locations, lengths of ruptures, can be proposed that account equally for these

564 observations. Given the resolution of our satellite images and the uncertainties in our offset

565 measurements, our analysis can hardly detect individual offsets below $2.5 \mathrm{~m}$ and thus slip events

566 of $\mathrm{Mw}<7$. We cannot rule out that some smaller slip events were not resolved by our analysis,

567 which would add some local variability of the slip distribution in the possible scenarios. The

568 amount of slip involved in these events would logically be smaller as well, and so the

569 uncertainties associated with them would not fundamentally change the proposed scenarios.

570 To assess the possible scenarios, we require independent constraints about the location, age and

571 characteristics of past earthquakes along the MNAF. Fortunately, the seismicity of the MNAF

572 region of the last two millennia is documented by significant written accounts (see e.g.

573 Ambraseys, 2009), archeological evidence (Benjelloun et al., 2018, 2020) and a few

574 paleoseismological investigations (see section 3). According to the slip rate estimates (sections 3

575 and 7.1), this time frame should correspond to a cumulative horizontal slip ranging between 6

576 and 10 meters. This includes between one and three COPD peaks, depending on segments. 


\section{$579 \quad 7.3$ Independent constraints on historical earthquakes along the MNAF}

\section{$580 \quad$ 7.3.1 Historical seismicity}

581 At least five destructive ruptures are documented in the historical seismicity catalogues for the 582 eastern part of the MNAF (Ambraseys, 2002, 2009; Ambraseys and Finkel, 1991, 1995;

583 Ambraseys and Jackson, 1998; Guidoboni et al., 1994; Fig. 2; Table S1). These events come 584 with high uncertainties on their location and magnitude, and it is generally difficult to locate the 585 ruptured fault from historical data only. Most of the information available relates to the cities of 586 Iznik and Gemlik. Excluding the earthquakes documented on the NNAF, Iznik was destroyed by 587 local earthquakes around 29-32 CE $\left(\mathrm{M}_{\mathrm{s}} 7\right)$, in $121 \mathrm{CE}\left(\mathrm{M}_{\mathrm{s}} 7.4\right)$, in $368 \mathrm{CE}\left(\mathrm{M}_{\mathrm{s}} 6.8\right)$, and $1065 \mathrm{CE}$ $588\left(M_{s} 6.8\right)$. The region of Gemlik was affected by the $M_{s} \sim 7.21419$ CE earthquake, which may 589 have originated from the SNAF system as no effect was reported in Iznik. A series of minor 590 ruptures, with estimated magnitudes about 5, are known between 1855 and 1863, also felt in 591 Gemlik and along the southern shore of Iznik Lake.

\section{$592 \quad$ 7.3.2 Archeoseismology}

593 Through an archeoseismological study in Iznik, Benjelloun et al. (2020) evidenced three

594 episodes of seismic damage in the city since the Roman period: (1) between the early $6^{\text {th }}$ and late $5958^{\text {th }}$ century CE, (2) between the mid- $9^{\text {th }}$ and late $11^{\text {th }}$ century CE, and (3) after the late $14^{\text {th }}$

596 century CE. These episodes were associated with a minimal intensity of VIII (EMS-98) in Iznik, 597 suggesting earthquakes of at least Mw 6. The modeling of a standing Roman obelisk north of the 598 city ruled out the occurrence of $\mathrm{Mw}>7.2$ ruptures along the fault section south of Iznik since the $5991^{\text {st }}$ century AD. 
601 Paleoseismological trenching works have documented mid-19 $9^{\text {th }}$ century events on segments A 602 and C. On segment A, a penultimate event was identified between the $12^{\text {th }}$ and $18^{\text {th }}$ centuries CE, 603 but was not seen in trenches located south of Iznik Lake. A possibly contemporaneous event was 604 also documented between the $14^{\text {th }}$ and $18^{\text {th }}$ centuries in a trench west of Mekece. On segment C, 605 one penultimate event was documented after the late $7^{\text {th }}$ century CE, and two older events were 606 identified before the mid- $5^{\text {th }}$ century CE in two trenches (see section 3, Fig. 2c). South of Iznik

607 Lake, Erginal et al. (2021) reported a $50 \mathrm{~cm}$ high coseismic scarplet in beachrock deposits that 608 they attributed to an $8^{\text {th }}$ century rupture.

609 Other important constraints can be derived from the lake core recently studied by Gastineau et al. 610 (2021). These sedimentary archives recorded the occurrence of several major earthquakes 611 documented both on the NNAF and MNAF, among which the 29-32 CE, $121 \mathrm{CE}, 1065 \mathrm{CE}$, and 612 an $8^{\text {th }}$ century CE event. The $1065 \mathrm{CE}$ earthquake ruptured a sublacustrine fault trace identified 613 within Iznik Lake, north of the onshore segment D. No event was recorded in these cores in the 614 eight centuries following the $1065 \mathrm{CE}$ earthquake, which strongly supports the absence of Mw > 6156.5 events on the central segments of the MNAF after $1065 \mathrm{CE}$. However, the lack of earthquake 616 recording after 1065 may be due to too low sedimentation rates in the lake in the last millennium, 617 even for large events located farther than $20-30 \mathrm{~km}$ from the lake.

\section{$618 \quad$ 7.3.4 Synthesis}

619 The events documented by at least two types of record, include the 29-32 ( $\left.\mathrm{M}_{\mathrm{s}} 7\right), 121\left(\mathrm{M}_{\mathrm{s}} 7.4\right)$, $6201065\left(M_{s} 6.8\right)$ and $1419\left(M_{s} 7.2\right)$ CE historical earthquakes. The precise location of the $1419 \mathrm{CE}$ 621 earthquake is not well constrained, but the fact that it was not recorded in the Iznik Lake cores 
622 nor in trenches south of Iznik Lake, and that destructions were only reported in the region of

623 Bursa, suggest that it did not extend east of Sölöz. To these we can add an $8^{\text {th }}$ century event

624 which affected the central MNAF segments south of Iznik Lake, and a $14^{\text {th }}-18^{\text {th }}$ century event

625 attested by some damaged buildings in Iznik and one trench on segment E.

626

\section{$627 \quad 7.4$ Analysis of COPD peak 1}

628 In a first assumption (Fig. 14b, scenario 1a), COPD peak 1 can be interpreted as a large Mw 7.2-

6297.4 event rupturing the whole length of the studied fault. This first interpretation involves

630 significant slip variations along strike, with slip values on the central segments C, D and E 33\%

631 lower than on the other segments. The hypothesis of differential preservation across segments

632 suggests another scenario (Fig. 14b, scenario 1b), with a more homogeneous slip of $\sim 4 \mathrm{~m}$ along

633 the studied section, only recovered on the central segments. Instead of decreasing slip on the

634 central segments as in the scenario 1a, this scenario involves a maximum slip in the central area,

635 which decrease towards both rupture tips. Given the higher structural complexity of this area,

636 lower horizontal slip values are expected along the central segments. Therefore, scenario 1a can

637 be considered more likely than scenario $1 \mathrm{~b}$. The favored historical candidate is the $1065 \mathrm{CE}$

638 earthquake, which is the best documented event. However, this means that the magnitude of the

$6391065 \mathrm{CE}$ earthquake, estimated at 6.8 by historical seismology studies, should be significantly

640 raised, by at least 0.3 units. It also implies that the $1065 \mathrm{CE}$ rupture identified in Iznik lake

641 propagated along the onshore fault segments as well. In addition, the deformation of the obelisk

642 north of Iznik does not support magnitudes over Mw 7.2 for events located south of Iznik, but

643 might be accounted for with a more distant epicenter, located on the western or eastern segments

This article is protected by copyright. All rights reserved. 
644 (Benjelloun et al., 2020).

645 Another possibility is to propose earthquakes rupturing only a part of the studied MNAF section,

646 with the central segments acting as a slip barrier (Fig. 14c, d). Following this hypothesis, COPD

647 peak 1 would correspond to two different earthquakes. These earthquakes ruptured different 648 sections of the fault, either adjacent (scenarios 2 and 3a) or overlapping (scenario 3b). The lower

649 slip values on the central segments are associated with the termination of earthquakes. In this 650 case, no significant slip variation appears along strike. The high slip values imply that the 651 ruptured area during these earthquakes could be respectively extended west of Gemlik and east 652 of the junction with the main NAF strand. This interpretation best accounts for the multiple 653 events found in the different records of past seismicity. The $1065 \mathrm{CE}$ earthquake is a favored 654 candidate for the western and central segments. The historical seismicity of the east of the 655 studied area is less documented, but the $14^{\text {th }}-18^{\text {th }} \mathrm{c}$. event found in the archeological and 656 paleoseismic record is a possible candidate for the eastern rupture of this scenario.

$658 \quad 7.5$ Analysis of COPD peak 2 and implications for the long-term behavior of the MNAF

659 The increments between COPD peaks 1 and 2 suggest that the slip values of the last and

660 penultimate events (or sequences of events) were comparable. Although the slip values estimated

661 for the penultimate event come with higher uncertainties, they also suggest magnitudes as high

662 as Mw 7.4 \pm 0.2 . The lacustrine record documents at least two events in the first centuries $\mathrm{CE}$

663 (Gastineau et al., 2021). The historical catalogues include two candidates, in 29-32 CE and in

$664121 \mathrm{CE}$, with poorly constrained locations along the MNAF. Both events can be accounted for 665 by interpreting peak 2 as two distinct ruptures (scenario 2, Fig. 14c). Given the uncertainties, a 
666 full MNAF rupture may also be proposed (scenarios 1 and 3, Fig. 14b and d).

667 The reconstructions of along-fault slip accumulation derived from systematic offset

668 measurements have been associated to the development of earthquake recurrence models

669 (Schwartz \& Coppersmith, 1984; Zielke et al., 2015). In our case, given the large uncertainties,

670 the successive increments on each segment cannot be unambiguously discriminated. Our dataset

671 remains compatible with a "characteristic slip" behavior, as in scenarios 1 and 2 (Fig. 14b, c),

672 where the earthquakes show recurring, similar slip distributions (see e. g. Klinger et al., 2011;

673 Kurtz et al., 2018; Zielke et al., 2010). In scenarios 1a and 2, the horizontal cumulative slip on

674 segments C, D and E is $25-35 \%$ lower than on the other segments for the last two events. This

675 cumulative slip deficit on the central segments produces a higher apparent slip rate variation

676 along-strike. The interpretations of scenario 3 depart from the characteristic slip model, as the

677 proposed distributions of the last events differ from the previous one, which resembles a variable

678 slip model.

679 The Late Quaternary slip accumulation along the MNAF seems dominated by large events with 680 comparable per-segment slip increments. This corresponds to the synoptic model of Zielke et al. 681 (2015), which also considers the occurrence of smaller ruptures contributing marginally to the 682 overall slip accumulation. The $8^{\text {th }}$ century CE event reported south of Iznik Lake (Erginal et al., 683 2021), and the $19^{\text {th }}$ century CE earthquakes reported in Gemlik (Özalp et al., 2013) may illustrate 684 these features. Future trenching work is needed to document the timing of earthquakes and to 685 judge between both models. 


\section{$688 \quad$ 7.6 Possible interactions between the NAF strands for the historical period}

689 In all the scenarios discussed, we can propose that the eastern MNAF has experienced two major

690 sequences of ruptures in the last two millennia. These historical sequences correspond to large

691 magnitude events, with amounts of slip ranging between 3.2 and $6.2 \mathrm{~m}$. Most of the deformation

692 was produced during intervals of high seismic activity, separated by longer quiescent periods

693 (1000-1500 years). This can be compared to the rupture history of other strike-slip fault systems

694 such as the San Andreas and Dead Sea faults (Lefevre et al., 2018; Rockwell et al., 2014). This

695 long recurrence time contrasts with the historical behavior of the NNAF (Fig. 2), and is

696 consistent with a slip rate $\sim 5$ times smaller on the MNAF. In the final part of this discussion, we

697 replace our propositions of past rupture history in the wider frame of the eastern Marmara region.

698 The last sequence of high seismicity along the MNAF, whatever the scenario considered, seems

699 to occur between the $11^{\text {th }}$ and $18^{\text {th }}$ centuries, while the northern strand of the NAF along the

700 Izmit Gulf (between $29.2^{\circ}$ and $30.3^{\circ} \mathrm{E}$ ) knew a period of lower seismic activity (Fig. 2b). The

7011065 CE earthquake was preceded by a major event on the NNAF in 1063 CE. However, it

702 mainly affected the western part of the Marmara region, with no significant damage reported east

703 of Constantinople (Ambraseys, 2009). Between the $14^{\text {th }}$ and $18^{\text {th }}$ centuries, only one major

704 earthquake is known for the eastern Marmara region in 1509 CE (M 7.2). The Gulf of Izmit was

705 likely affected by this earthquake (Klinger et al., 2003), but the contemporary historical records

706 do not account for heavy damage farther east (Ambraseys, 2001b). After this earthquake, a

707 quiescence period is reported for the Marmara region between 1509 and 1719 CE (Ambraseys \&

708 Jacskon, 2000; Pondard et al., 2007; Rockwell et al., 2009).

709 By contrast, the southern strands of the NAF were marked by a significant seismic activity in the

This article is protected by copyright. All rights reserved. 
710 east of the Marmara Sea. After the 1065 CE earthquake on the MNAF, this activity seems to

711 restart in the early $15^{\text {th }}$ century CE. It includes the 1419 CE earthquake which affected the Bursa

712 region, and the event proposed between the $14^{\text {th }}$ and $18^{\text {th }}$ centuries CE along the eastern segments

713 of the MNAF (scenarios 2 and 3). This earthquake may have propagated across the junction with

714 the main NAF strand. The junction zone does not present any significant step-over, but only an

715 azimuth change of $\sim 20^{\circ}$. The $1967 \mathrm{CE}$ earthquake propagated across this junction between the

716 main NAF and the NNAF, with a similar azimuth difference. Therefore, a symmetrical rupture

717 between the main NAF and the MNAF is not unrealistic. A trenching study carried out by

718 Palyvos et al. (2007) in the Mudurnu valley, located a few kilometers east of the junction with

719 the main NAF strand, identified at least one and most probably two paleoevents younger than

$7201693 \mathrm{CE}$. Some of these ruptures may have propagated across the junction along the MNAF.

721 Analogous alternations of active and quiescent phases between adjacent fault strands have been

722 previously identified on the San Andreas fault system in relation to the San Jacinto fault (Lozos,

723 2016; Onderdonk et al., 2018). In the case of the NAF in the Marmara region, the investigation

724 of older sedimentary records of past earthquakes on the different strands might better document

725 this behavior and check for earlier occurrences of it.

726

\section{Conclusion}

728 By combining field observations and the analysis of high-resolution satellite images, we have

729 demonstrated that the segments constituting the MNAF in the southeast of the Marmara region

730 have been significantly active during the Holocene. The fault displays morphological features

731 typical of strike-slip deformation, associated locally with a smaller vertical component. We

This article is protected by copyright. All rights reserved. 
732 collected 114 measurements of horizontally offset markers, providing evidence for large,

733 repeated earthquakes along the MNAF. Through a statistical analysis of the offsets, we

734 particularly documented at least two major surface-rupturing earthquakes whose deformation

735 was preserved in the landscape. They are characterized by coseismic horizontal displacement

736 ranging from 3.2 to $6.2 \mathrm{~m}$, which indicates moment magnitudes ranging between $7.2 \pm 0.2$ and

$737 \quad 7.4 \pm 0.2$ according to empirical scaling laws. Some of these events may have ruptured the whole

738 eastern MNAF section along more than $100 \mathrm{~km}$. Although smaller earthquakes also happened in

739 the past, our analysis may not resolve accurately their frequency due to the data uncertainties and

740 preservation issues. According to the historical catalogues of seismicity and paleoseismological

741 studies, the last large events documented along this fault strand possibly happened in $1065 \mathrm{CE}$,

742 or between the $14^{\text {th }}$ and $18^{\text {th }}$ centuries CE along the eastern segments. These intervals correspond

743 to a period of relative quiescence along the NNAF segments located east of the Marmara Sea.

744 We estimated a late Holocene horizontal slip rate of $\mathbf{4 . 4}+\mathbf{4} . \mathbf{1 0 . 6} \mathrm{mm} / \mathrm{yr}$ on the central MNAF

745 segments. Since the last large events, the eastern MNAF segments may have accumulated stress

746 equivalent to 1-4 $\mathrm{m}$ of horizontal deformation. Therefore, the current level of stress may be

747 enough to generate a significant earthquake, comparable or larger than a $1065 \mathrm{CE}$ type rupture,

748 which caused important damage in Iznik. The activity of the southern strands of the NAF should

749 not be neglected in terms of slip history and should be considered into any seismic hazard

750 assessment.

751

\section{Data Availability Statement}

753 The bathymetric map of Marmara was made available by the EMODnet Bathymetry project

This article is protected by copyright. All rights reserved. 
754 (https://www.emodnet.eu/bathymetry), using the EMODnet Bathymetry portal (EMODnet 755 Bathymetry Consortium, 2016, EMODnet Digital Bathymetry [DTM], DOI:

756 10.12770/c7b53704-999d-4721-b1a3-04ec60c87238) funded by the European Commission

757 Directorate General for Maritime Affairs and Fisheries. The large-scale topography of the study

758 area was obtained from the Shuttle Radar Topography Mission 1 Arc-Second Global

759 (DOI:10.5066/F7PR7TFT). The bathymetry of İznik Lake was provided by and can be obtained 760 from the Turkish General Directorate of Hydraulic Works (DSI). Pleiades imagery is available

761 for purchase from Airbus industry (https://www.intelligence-airbusds.com/en/8692- pleiades).

762 The full offset retro-deformation dataset and a vector file of the fault map are available on the

763 Zenodo repository (Benjelloun et al., 2021) [open access]. The maps of Figures 5 are from

764 Google Earth satellite imagery. The diagrams of Figures 6, 7, 8 and 14 were prepared using the 765 Matplotlib 3.3.0 package for Python (https://matplotlib.org/; Hunter, 2007). All websites were

766 last accessed in January 2021. Supporting Information for this article includes a detailed

767 explanation of the marker quality score determination, a list of historical earthquakes in the area

768 of interest, a summary of paleoseismic trenching works done in the area, the offset measurement

769 data, and supplementary figures on the vertical slip markers south of Iznik Lake, some field

770 examples of Quaternary faulting, and the automatic fault discretization procedure.

\section{Acknowledgments}

773 This work has been supported by the Mediterranean Integrated STudies at Regional And Local

774 Scales - ENVIronment of the MEDiterranean (MISTRALS-ENVIMED) program (The North

775 Anatolian Fault in the region Iznik: Geomorphological Evolution and Archaeoseismicity 
776 [NAFIGEA] project), the Institut National des Sciences de l'Univers (INSU) Aleas program 777 (France), and the ANR CE03-2019 Basiliznik-secrets. The Pleiades images were bought with 778 support from LabEx OSUG@2020 (Investissements d'avenir - ANR10 LABX56, France). This 779 study contributes to the IdEx Université de Paris ANR-18-IDEX-0001. The authors warmly 780 thank the ASTER team (D. Bourlès, G. Aumaitre, K. Keddadouche, and R. Braucher) for the 781 measurements performed at the ASTER AMS facility (CEREGE, Aix-en-Provence). We thank 782 the Turkish Ministry of Culture and Tourism for allowing the field work. We thank Pr. Mustafa 783 Sahin and his research group, and the Kandilli observatory in Iznik for their help with logistics 784 and housing. The authors declare no conflict of interests.

\section{References}

787 Aki, K. (1984). Asperities, barriers, characteristic earthquakes and strong motion prediction. 788 Journal of Geophysical Research: Solid Earth, 89(B7), 5867-5872.

789 Akyüz, S., Dogan, B., Aksoy, M. E., Tigli, O., \& Zabci, C. (2014). Preliminary

790 Palaeoseismological results of the Middle Strand of the North Anatolian Fault (NAF) in the 791 Marmara Region, NW Turkey. Paper presented at European Geosciences Union General 792 Assembly, Vienna, Austria.

793 Akyüz, H. S., Hartleb, R., Barka, A., Altunel, E., Sunal, G., Meyer, B., \& Armijo, R. (2002).

794 Surface rupture and slip distribution of the 12 November 1999 Düzce earthquake (M 7.1), North 795 Anatolian fault, Bolu, Turkey. Bulletin of the Seismological Society of America, 92(1), 61-66.

796 https://doi.org/10.1785/0120000840

797 Akyuz, H. S. \& Zabci, C. (2012). A review of paleoseismic investigations along the North 
798 Anatolian Fault, Turkey. Paper presented at PANAF: Paleoseismology Along the North 799 Anatolian Fault Meeting, Istanbul, Turkey.

800 Ambraseys, N. N. (1970). Some Characteristic Features of the Anatolian Fault Zone.

801 Tectonophysics, 9, 143-165. https://doi.org/10.1016/0040-1951(70)90014-4

802 Ambraseys, N. (2000). The Seismicity of the Marmara Sea Area 1800-1899. Journal of

803 Earthquake Engineering, 4(3), 377-401. https://doi.org/10.1080/13632460009350376

804 Ambraseys, N. N. (2001a). Reassessment of earthquakes, 1900-1999, in the eastern

805 Mediterranean and the Middle East. Geophysical Journal International, 145(2), 471-485.

806 https://doi.org/10.1046/j.0956-540x.2001.01396.x

807 Ambraseys, N. N. (2001b). The Earthquake of 1509 in the Sea of Marmara, Turkey, Revisited.

808 Bulletin of the Seismological Society of America, 91(6), 1397-1416.

809 https://doi.org/10.1785/0120000305

810 Ambraseys, N. (2002). The seismic activity of the Marmara Sea region over the last 2000 years. 811 Bulletin of the Seismological Society of America, 92(1), 1-18.

812 https://doi.org/10.1785/0120000843

813 Ambraseys, N. (2009). Earthquakes in the Mediterranean and Middle East. A multidisciplinary

814 study of seismicity up to 1900. Cambridge: Cambridge University Press.

815 https://doi.org/10.1017/CBO9781139195430

816 Ambraseys, N. \& Finkel, C. (1991). Long-term seismicity of Istanbul and of the Marmara Sea

817 region. Terra Nova, 3(5), 527-539. https://doi.org/10.1111/j.1365-3121.1991.tb00188.x

818 Ambraseys, N. N., \& Finkel, C. F. (1995). The Seismicity of Turkey and Adjacent Areas: A 
819 Historical Review, 1500-1800. Istanbul: Muhittin Salih Eren.

820 Ambraseys, N. N., \& Jackson, J. (1998). Faulting associated with historical and recent

821 earthquakes in the eastern Mediterranean region. Geophysical Journal International, 133(2),

822 390-406. https://doi.org/10.1046/j.1365-246X.1998.00508.x

823 Ambraseys, N.N., \& Jackson, J.A. (2000). Seismicity of the Sea of Marmara (Turkey) since

824 1500. Geophysical Journal International, 141(3), F1-F6. https://doi.org/10.1046/j.1365-

$825246 x .2000 .00137 . x$

826 Ambraseys, N. N., Jackson, J. A., \& Melville, C. P. (2002). Historical Seismicity and Tectonics:

827 The Case of the Eastern Mediterranean and the Middle East. In W. H. K. Lee, H. Kanamori, P.

828 C. Jennings, C. Kisslinger (Eds.). International Handbook of Earthquake and Engineering

829 Seismology (Part A, pp. 747-763). Cambridge, MA: Academic Press.

830 https://doi.org/10.1016/S0074-6142(02)80248-0

831 Ansberque, C., Bellier, O., Godard, V., Lasserre, C., Wang, M., Braucher, R., et al. (2016). The

832 Longriqu fault zone, eastern Tibetan Plateau: Segmentation and Holocene behavior. Tectonics, $833 \quad 35(3), 565-585$.

834 Antoine, S. L., Klinger, Y., Delorme, A., Wang, K., Bürgmann, R., \& Gold, R. (2021). Diffuse

835 Deformation and Surface Faulting Distribution from Submetric Image Correlation along the 8362019 Ridgecrest, California, Ruptures. Bulletin of the Seismological Society of America,

837 https://doi.org/10.1785/0120210036

838 Armijo, R., Meyer, B., Hubert, A., \& Barka, A. A. (1999). Westward propagation of the North 839 Anatolian fault into the northern Aegean: Timing and kinematics. Geology, 27, 267-270. 
841 Armijo, R., Meyer, B., King, G. C. P., Rigo, A., \& Papanastassiou, D. (1996). Quaternary

842 evolution of the Corinth Rift and its implications for the Late Cenozoic evolution of the Aegean.

843 Geophysical Journal International, 126(1), 11-53. https://doi.org/10.1111/j.1365-

844 246X.1996.tb05264.x

845 Armijo, R., Meyer, B., Navarro, S., King, G., \& Barka, A. (2002). Asymmetric slip partitioning 846 in the Sea of Marmara pull-apart: a clue to propagation processes of the North Anatolian Fault?

847 Terra Nova, 14(2), 80-86. https://doi.org/10.1046/j.1365-3121.2002.00397.x

848 Arnold, M., Merchel, S., Bourlès, D. L., Braucher, R., Benedetti, L., Finkel, R. C., et al. (2010).

849 The French accelerator mass spectrometry facility ASTER: Improved performance and

850 developments. Nuclear Instruments and Methods in Physics Research Section B: Beam

851 Interactions with Materials and Atoms, 268, 1954-1959.

852 https://doi.org/10.1016/j.nimb.2010.02.107

853 Balco, G., Stone, J. O., Lifton, N. A., \& Dunai, T. J. (2008). A complete and easily accessible 854 means of calculating surface exposure ages or erosion rates from ${ }^{10} \mathrm{Be}$ and ${ }^{26} \mathrm{Al}$ measurements. 855 Quaternary Geochronology, 3(3), 174 - 195. https://doi.org/10.1016/j.quageo.2007.12.001

856 Baris, S., Ito, A., Üçer, S. B., Honkura, Y., Kafadar, N., Pektas, R., et al. (2002).

857 Microearthquake Activity before the Izmit Earthquake in the Eastern Marmara region, Turkey (1 858 January 1993-17 August 1999). Bulletin of the Seismological Society of America, 92(1), 394 859 405. https://doi.org/10.1785/0120000826

860 Barka, A. (1992). The North Anatolian fault zone. Annales Tectonicae, 6, 164-195.

861 Barka, A. (1993). Kuzey Anadolu Fayı'nın Sapanca-Izmit ve Geyve-Iznik Kolları üzerinde

862 Palaeosismik Arastırmalar (Technical Report YBAG-4/7551). Istanbul: TÜBITAK. 
863 Barka, A. (1996). Slip distribution along the North Anatolian fault associated with the large 864 earthquakes of the period 1939 to 1967. Bulletin of the Seismological Society of America, 86(5), $865 \quad 1238-1254$.

866 Barka, A., Akyüz, H. S., Altunel, E., Sunal, G., Cakir, Z., Dikbas, A., et al. (2002). The Surface

867 Rupture and Slip Distribution of the 17 August 1999 Izmit Earthquake (M 7.4), North Anatolian 868 Fault. Bulletin of the Seismological Society of America, 92(1), 43-60.

869 https://doi.org/10.1785/0120000841

870 Barka, A. \& Kadinsky-Cade, K. (1988). Strike-slip fault geometry in Turkey and its influence on 871 earthquake activity. Tectonics, 7(3), 663-684.

872 Beauprêtre, S., Garambois, S., Manighetti, I., Malavieille, J., Sénéchal, G., Chatton, M., et al.

873 (2012). Finding the buried record of paste earthquakes with GPR-based palaeoseismology: a case 874 study on the Hope fault, New Zealand. Geophysical Journal International, 189(1), 73-100.

875 https://doi.org/10.1111/j.1365-246X.2012.05366.X

876 Beauprêtre, S., Manighetti, I., Garambois, S., Malavieille, J., \& Dominguez, S. (2013).

877 Stratigraphic architecture and fault offsets of alluvial terraces at Te Marua, Wellington fault,

878 New Zealand, revealed by pseudo-3D GPR investigation. Journal of Geophysical Research:

879 Solid Earth, 118, 4564-4585.

880 Benjelloun, Y., de Sigoyer, Dessales, H., Baillet, L., Guéguen, P., \& Sahin, M. (2020). Historical 881 Earthquake Scenarios for the Middle Strand of the North Anatolian Fault Deduced from Archeo882 Damage Inventory and Building Deformation Modeling. Seismological Research Letters, 92, 883 583-598. https://doi.org/10.1785/0220200278

884 Benjelloun, Y., de Sigoyer, J., Dessales, H., Garambois, S., \& Sahin, M. (2018). Construction 
885 history of the aqueduct of Nicaea (Iznik, NW Turkey) and its on-fault deformation viewed from 886 archaeological and geophysical investigations. Journal of Archaeological Science: Reports, 21, 887 389-400. https://doi.org/10.1016/j.jasrep.2018.08.010

888 Benjelloun, Y., de Sigoyer, J., Garambois, S., Carcaillet, J., \& Klinger, Y. (2021). Data for: 889 Segmentation and Holocene Behavior of the Middle Strand of the North Anatolian Fault (NW 890 Turkey) (Version 1.2.0) [Data set]. Zenodo. http://doi.org/10.5281/zenodo.5566874

891 Broxton, M. J. \& Edwards, L. J. (2008). The Ames Stereo Pipeline: Automated 3D Surface 892 Reconstruction from Orbital Imagery. Paper presented at the $39^{\text {th }}$ Lunar and Planetary Science 893 Conference, League City, TX.

894 Brown, E. T., Edmond, J. M., Raisbeck, G. M., Yiou, F., Kurz, M. D., \& Brook, E. J. (1991). 895 Examination of surface exposure ages of Antarctic moraines using in situ produced ${ }^{10} \mathrm{Be}$ and $896{ }^{26}$ Al. Geochimica et Cosmochimica Acta, 55, 2269-2283. https://doi.org/10.1016/0016$897 \quad 7037(91) 90103-\mathrm{C}$

898 Chaput, E. (1936). Voyages d'études géologique et géomorphogéniques en Turquie. Paris : De 899 Boccard.

900 Chmeleff, J., von Blanckenburg, F., Kossert, K., \& Jakob, D. (2010). Determination of the ${ }^{10} \mathrm{Be}$ 901 half-life by multicollector ICP-MS and liquid scintillation counting. Nuclear Instruments and 902 Methods in Physics Research Section B: Beam Interactions with Materials and Atoms, 268(2), 903 192-199. https://doi.org/10.1016/j.nimb.2009.09.012

904 Choi, J. H., Klinger, Y., Ferry, M., Ritz, J. F., Kurtz, R., Rizza, M. et al. (2018). Geologic 905 Inheritance and Earthquake Rupture Processes: The 1905 M $\geq 8$ Tsetserleg-Bulnay Strike-Slip 906 Earthquake Sequence, Mongolia. Journal of Geophysical Research: Solid Earth, 123. 
907 https://doi.org/10.1002/2017JB013962.

908 Civico, R., Smedile, A., Pantosti, D., Cinti, F. R., De Martini, P. M., Pucci, S., et al. (2021). New

909 trenching results along the Iznik segment of the central strand of the North Anatolian Fault

910 (Turkey): an integration with preexisting data. Mediterranean Geoscience Reviews, 3, 115-128.

911 https://doi.org/10.1007/s42990-021-00054-9

912 de Michele, M., Raucoules, D., de Sigoyer, J., Pubellier, M., \& Chamot-Rooke, N. (2010).

913 Three-dimensional surface displacement of the 2008 May 12 Sichuan earthquake (China)

914 derived from Synthetic Aperture Radar: evidence for rupture on a blind thrust. Geophysical

915 Journal International, 183(3), 1097-1103. https://doi.org/10.1111/j.1365-246X.2010.04807.x

916 Dikbas, A., Akyüz, H. S., Meghraoui, M., Ferry, M., Altunel, E., Zabci, C., et al. (2018).

917 Paleoseismic history and slip rate along the Sapanca-Akyazi segment of the 1999 Izmit

918 earthquake rupture (MW=7.4) of the North Anatolian Fault (Turkey). Tectonophysics, 738-739,

919 92-111. https://doi.org/10.1016/j.tecto.2018.04.019

920 Dogan, B. (2010). Kuzey Anadolu Fay Sistemi Güney Kolunun Geyve-Gemlik Arasindaki

921 Kesiminin Morfotektonik, Tektonostratigrafik ve Palaeosismolojik Evrimi. (Doctoral

922 dissertation). Istanbul: Istanbul Teknik Üniversitesi.

923 Elliott, J. R., Walters, R. J., \& Wright, T. J. (2016). The role of space-based observation in

924 understanding and responding to active tectonics and earthquakes. Nature Communications, 7 ,

925 13844. https://doi.org/10.1038/ncomms13844

926 Emre, Ö., Duman, T. Y., \& Özalp, S. (2011). 1:250.000 Ölçekli Türkiye Diri Fay Haritası Serisi.

927 (Technical report). Ankara: Maden Tetkik ve Arama Genel Müdürlügü.

928 Erginal, A. E., Erenoglu, R. C., Yildirim, C., Selim, H., H., Kiyak, N. G, Erenoglu, O, et al. 
929 (2021). Co-seismic beachrock deformation of 8th century CE Earthquake in Middle Strand of

930 North Anatolian Fault, Lake Iznik, NW Turkey. Tectonophysics, 799, 2286990.

931 https://doi.org/10.1016/j.tecto.2020.228690

932 Ergintav, S., Reilinger, R. E., Çakmak, R., Floyd, M., Cakir, Z., Dogan, U., et al. (2014).

933 Istanbul's earthquake hot spots: Geodetic constraints on strain accumulation along faults in the 934 Marmara seismic gap. Geophysical Research Letters, 41(16), 5783-5788.

935 https://doi.org/10.1002/2014GL060985

936 Flerit, F., Armijo, R., King, G. C. P., Meyer, B., \& Barka, A. (2003). Slip partitioning in the Sea

937 of Marmara pull-apart determined from GPS velocity vectors. Geophysical Journal

938 International, 154(1), 1-7. https://doi.org/10.1046/j.1365-246X.2003.01899.X

939 Fletcher, J. M., Teran, O. J., Rockwell, T. K., Oskin, M. E., Hudnut, K., W., Mueller, K. J., et al. 940 (2014). Assembly of a large earthquake from a complex fault system: Surface rupture kinematics 941 of the 4 April 2010 El Mayor - Cucapah (Mexico) $\mathrm{M}_{\mathrm{w}} 7.2$ earthquake. Geosphere, 10(4), 797 $942 \quad 827$. https://doi.org/10.1130/GES00933.1

943 Fraser, J., Vanneste, K., \& Hubert-Ferrari, A. (2010). Recent behavior of the North Anatolian

944 Fault: Insights from an integrated palaeoseismological data set. Journal of Geophysical

945 Research: Solid Earth, 115(B9): B09316.

946 Fu, B., Ninomiya, Y., Lei, X., Toda, S., \& Awata, Y. (2004). Mapping active fault associated 947 with the $2003 \mathrm{Mw}$ 6.6 Bam (SE Iran) earthquake with ASTER 3D images. Remote Sensing of 948 Environment, 92(2), 153-157. https://doi.org/10.1016/j.rse.2004.05.019

949 Gastineau, R., de Sigoyer, J., Sabatier, P., Fabbri, S. C., Anselmetti, F. S., Develle, A. L., et al. 950 (2021). Active subaquatic fault segments in Lake Iznik along the middle strand of the North 
951 Anatolian Fault, NW Turkey. Tectonics, 40, e2020TC006404.

952 Gasperini, L., Polonia, A., Çagatay, M. N., Bortoluzzi, G., \& Ferrante, V. (2011). Geological

953 slip rates along the North Anatolian Fault in the Marmara region. Tectonics, 30(6), TC6001.

954 Gold, P. O., Oskin, M. E., Elliott, A. J., Hinojosa-Corona, A., Taylor, M. H., Kreylos, O., \&

955 Cowgill, E. (2013). Coseismic slip variation assessed from terrestrial lidar scans of the El

956 Mayor-Cucapah surface rupture. Earth and Planetary Science Letters, 366, 151-162.

957 https://doi.org/10.1016/j.eps1.2013.01.040

958 Grall, C., Henry, P., Thomas, Y., Westbrook, G.K., Çağatay, M.N., Marsset, B., et al. (2013).

959 Slip rate estimation along the western segment of the Main Marmara Fault over the last 405-490

960 ka by correlating mass transport deposits. Tectonics, 32, 2012TC003255.

961 doi:10.1002/2012TC003255.

962 Guidoboni, E., and Comastri, A. (Eds.) (2005). Catalogue of Earthquakes and Tsunamis in the

963 Mediterranean Area From the 11th to the 15th Century. Roma: Istituto Nazionale di Geofisica e

964 Vulcanologia.

965 Guidoboni, E., Comastri, A., \& Traina, G. (1994). Catalogue of ancient earthquakes in the

966 Mediterranean area up to the $10^{\text {th }}$ century. Roma: Istituto Nazionale di Geofisica.

967 Gürbüz, C., Aktar, M., Eyidogan, H., Cisternas, A., Haessler, H., Barka, A., et al. (2000). The

968 seismotectonics of the Marmara region (Turkey): results from a microseismic experiment.

969 Tectonophysics, 316(1), 1-17. https://doi.org/10.1016/S0040-1951(99)00253-X

970 Hamling, I. J., Hreinsdottir, S., Clark, K., Elliott, J., Liang, C., Fielding, E., et al. (2017).

971 Complex multifault rupture during the 20167.8 Kaikoura earthquake, New Zealand. Science,

972 356(6334), eaam7194. DOI: 10.1126/science.aam7194

This article is protected by copyright. All rights reserved. 
973 Heisinger, B., Lal, D., Jull, A., Kubik, P., Ivy-Ochs, S., Knie, K., \& Nolte, E. (2002a),

974 Production of selected cosmogenic radionuclides by muons: 2. capture of negative muons. Earth

975 and Planetary Science Letters, 200(3), 357 - 369. https://doi.org/10.1016/S0012-

$976 \quad 821 X(02) 00641-6$

977 Heisinger, B., Lal, D., Jull, A., Kubik, P., Ivy-Ochs, S., Neumaier, S., Knie, K., Lazarev, V., \&

978 Nolte, E. (2002b). Production of selected cosmogenic radionuclides by muons: 1. fast muons.

979 Earth and Planetary Science Letters, 200(3), 345 - 355. https://doi.org/10.1016/S0012-

$980 \quad 821 X(02) 00640-4$

981 Hidy, A. J., Gosse, J. C., Pederson, J. L., Mattern, J. P., \& Finkel, R. C. (2010). A geologically

982 constrained Monte Carlo approach to modeling exposure ages from profiles of cosmogenic

983 nuclides: An example from Lees Ferry, Arizona. Geochemistry, Geophysics, Geosystems, 11(9),

984 Q0AA10. https://doi.org/10.1029/2010GC003084

985 Honkura, Y. \& Isikara, A. M. (1991). Multidisciplinary research on fault activity in the western

986 part of the North Anatolian Fault Zone. Tectonophysics, 193(4), 347-357.

987 https://doi.org/10.1016/0040-1951(91)90343-Q

988 Hubert-Ferrari, A., Barka, A., Jacques, E., Nalbant, S. S., Meyer, B., Armijo, R., et al. (2000).

989 Seismic hazard in the Marmara Sea region following the 17 August 1999 Izmit earthquake.

990 Nature, 404(6775), 269-273. https://doi.org/10.1038/35005054

991 Hubert-Ferrari, A., King., G., van der Woerd, J., Villa, I., Altunel, E., \& Armijo, R. (2002).

992 Long-term evolution of the North Anatolian Fault: new constraints from its eastern termination.

993 In D. J. J. van Hinsbergen, M. A. Edwards, R. Govers (Eds.), Collision and Collapse at the

994 Africa-Arabia-Eurasia Subduction Zone, Geological Society Special Publications (Vol. 311, pp.

This article is protected by copyright. All rights reserved. 
995 133-154). London: The Geological Society. doi: 10.1144/SP311.5

996 Hunter, J. D. (2007). Matplotlib: A 2D graphics environment. Computing in Science \&

997 Engineering, 9, 90-95. https://doi.org/10.1109/MCSE.2007.55

998 Ikeda, Y. (1988). Recent activity of the Iznik-Mekece fault at Corak Stream, east of Iznik. In Y.

999 Honkura,A. M. Isikara (Eds.), Multidisciplinary research on fault activity in the western part of 1000 the North Anatolian Fault Zone (pp. 15-27). Tokyo: Institute of Technology.

1001 Ikeda, Y. (1988). Recent activity of the Iznik-Mekece fault at Corak Stream, east of Iznik. In Y.

1002 Honkura, A. M. Isikara (Eds.), Multidisciplinary research on fault activity in the western part of 1003 the North Anatolian Fault Zone (pp. 15-27). Tokyo: Institute of Technology.

1004 Ikeda, Y., Herece, E., Sugai, T., \& Isikara, A. M. (1991). Postglacial crustal deformation 1005 associated with slip on the western part of the North Anatolian Fault Zone in the Iznik Lake 1006 Basin, Turkey. Bulletin of the Department of Geography University of Tokyo, 23, 13-23.

1007 Ikeda, Y., Suzuki, Y., \& Herece, E. (1989). Late Holocene activity of the North Anatolian fault 1008 zone in the Orhangazi plain, northwestern Turkey. In Y. Honkura, A. M. Isikara (Eds.), 1009 Multidisciplinary research on fault activity in the western part of the North Anatolian fault zone 1010 (Vol. 2, pp. 16-30). Tokyo: Institute of Technology.

1011 Ikeda, Y., Suzuki, Y., Herece, E., Saroglu, F., Isikara, A. M., \& Honkura, Y. (1991). Geological 1012 evidence for the last two faulting events on the north Anatolian Fault zone in the Mudurnu 1013 Valley, western Turkey. Tectonophysics, 193(4), 335-345. https://doi.org/10.1016/00401014 1951(91)90342-P

1015 Ketin, I. (1969). Kuzey Anadolu Fayi Hakkinda. Maden Tektik ve Arama Dergisi, 72, 1-27.

1016 Ketin, I., \& Rösli, F. (1953). Makroseismische Untersuchungen über das nordwest-anatolische 
1017 Beben vom 18 März 1953. Eclogae Geologicae Helvetiae, 46, 187-208.

1018 Kim, S. J., Koh, K., Boyd, S., \& Gorinevsky, D. (2009). 11 trend filtering. SIAM Review, 51(2), 1019 339-360. https://doi.org/10.1137/070690274

1020 King, G., \& Nabelek, J. (1985). Role of Fault Bends in the Initiation and Termination of 1021 Earthquake Rupture. Science, 228(4702), 984-987. DOI: 10.1126/science.228.4702.984

1022 King., G., Klinger, Y., Bowman, D., \& Tapponnier, P. (2005). Slip-Partitioned Surface Breaks 1023 for the $\mathrm{M}_{\mathrm{w}} 7.82001$ Kokoxili Earthquake, China. Bulletin of the Seismological Society of 1024 America, 95(2), 731-738. doi: 10.1785/0120040101

1025 Klinger, Y. (2010). Relation between continental strike-slip earthquake segmentation and 1026 thickness of the crust. Journal of Geophysical Research: Solid Earth, 115, B07306.

1027 Klinger, Y., Etchebes, M., Tapponnier, P., \& Narteau, C. (2011). Characteristic slip for five great 1028 earthquakes along the Fuyun fault in China. Nature Geoscience, 4(6), 389-392.

1029 https://doi.org/10.1038/ngeo1158

1030 Klinger, Y., Sieh, K., Altunel, E., Akoglu, A., Barka, A., Dawson, T., et al. (2003).

1031 Palaeoseismic Evidence of Characteristic Slip on the Western Segment of the North Anatolian 1032 Fault, Turkey. Bulletin of the Seismological Society of America, 93(6), 2317-2332.

1033 https://doi.org/10.1785/0120010270

1034 Klinger, Y., Xu, X., Tapponnier, P., Van der Woerd, J., Lasserre, C., \& King, G. (2005). High1035 Resolution Satellite Imagery Mapping of the Surface Rupture and Slip Distribution of the $\mathbf{M}_{\mathrm{w}}$ $1036 \sim 7.8,14$ November 2001 Kokoxili Earthquake, Kunlun Fault, Northern Tibet, China. Bulletin of 1037 the Seismological Society of America, 95(5), 1970-1987. http://dx.doi.org/10.1785/0120040233

1038 Koçyigit, A. (1988). Tectonic setting of the Geyve Basin: age and total displacement of the 
1039 Geyve Fault Zone. Journal of Pure and Applied Sciences, 21, 81-104.

1040 Koçyigit, A. \& Özacar, A. A. (2003). Extensional neotectonic regime through the NE edge of the 1041 outer Isparta Angle, SW Turkey: new field and seismic data. Turkish Journal of Earth Sciences, 1042 12(1), 67-90.

1043 Kozaci, Ö., Dolan, J. F., \& Finkel, R. C. (2009). A late Holocene slip rate for the central North 1044 Anatolian fault, at Tahtaköprü, Turkey, from cosmogenic ${ }^{10} \mathrm{Be}$ geochronology: Implications for 1045 fault loading and strain release rates. Journal of Geophysical Research: Solid Earth, 114(B1), 1046 B01405. https://doi.org/10.1029/2008JB005760

1047 Kozaci, Ö., Dolan, J. F., Finkel, R., \& Hartleb, R. (2007). Late Holocene slip rate for the North 1048 Anatolian fault, Turkey, from cosmogenic 36Cl geochronology: Implications for the constancy 1049 of fault loading and strain release rates. Geology, 35(10), 867-870.

1050 https://doi.org/10.1130/G23187A.1

1051 Kürçer, A., Chatzipetros, A., Tutkun, S. Z., Pavlides, S., Özkan Ates, \& Valkaniotis, S. (2008).

1052 The Yenice-Gönen active fault (NW Turkey): Active tectonics and palaeoseismology.

1053 Tectonophysics, 453(1), 263 - 275. https://doi.org/10.1016/j.tecto.2007.07.010

1054 Kürcer, A., Özalp, S., Özdemir, E., Uygun Güldogan, C., \& Duman, T. Y. (2019). Active

1055 tectonics and paleoseismologic characteristics of the Yenice-Gönen fault, NW Turkey, in light of 1056 the 18 March 1953 Yenice-Gönen Earthquake (Ms=7.2). Maden Tektik ve Arama Dergisi, 159, 1057 29-62. https://doi.org/10.19111/bulletinofmre.500553

1058 Kurt, H., Sorlien, C.C., Seeber, L., Steckler, M.S., Shillington, D.J., Cifci, G., et al. (2013).

1059 Steady late quaternary slip rate on the Cinarcik section of the North Anatolian fault near Istanbul, 1060 Turkey. Geophysical Research Letters, 40, 4555-4559. doi:10.1002/grl.50882. 
1061 Kurtz, R., Klinger, Y., Ferry, M., \& Ritz, J. F. (2018). Horizontal surface-slip distribution 1062 through several seismic cycles: The Eastern Bogd fault, Gobi-Altai, Mongolia. Tectonophysics, 1063 734-735, 167-182. https://doi.org/10.1016/j.tecto.2018.03.011

1064 Lafarge, T., \& Possolo, A. (2016). The NIST Uncertainty Machine. NCSLI Measure, 10(3), 201065 27. DOI: $10.1080 / 19315775.2015 .11721732$

1066 Le Béon, M., Klinger, Y., Al-Qaryouti, M., Mériaux, A. S., Finkel, R., C., Elia, A., et al. (2010). 1067 Early Holocene and Late Pleistocene slip rates of the southern Dead Sea Fault determined from 1068 10Be cosmogenic dating of offset alluvial deposits. Journal of Geophysical Research: Solid 1069 Earth, 115, B11414, doi:10.1029/2009JB007198.

1070 Lefevre, M., Klinger, Y., Al-Qaryouti, M., Le Béon, M., \& Moumani, K. (2018). Slip deficit and 1071 temporal clustering along the Dead Sea fault from palaeoseismological investigations. Scientific 1072 Reports, 8, doi:10.1038/s41598-018-22627-9.

1073 Le Pichon, X., Imren, C., Rangin, C., Sengör, A. M. C., \& Siyako, M. (2014). The South 1074 Marmara Fault. International Journal of Earth Sciences, 103(1), 219-231.

1075 https://doi.org/10.1007/s00531-013-0950-0

1076 Lifton, N. (2016). Implications of two Holocene time dependent geomagnetic models for 1077 cosmogenic nuclide production rate scaling. Earth and Planetary Science Letters, 433, 257-268. 1078 https://doi.org/10.1016/j.eps1.2015.11.006

1079 Lifton, N. A., Sato, T., \& Dunai, T. J. (2014). Scaling in situ cosmogenic nuclide production 1080 rates using analytical approximations to atmospheric cosmic-ray fluxes. Earth and Planetary 1081 Science Letters, 386, 149-160. https://doi.org/10.1016/j.eps1.2013.10.052

1082 Lin, Z., Liu-Zeng, J., Weldon II, R. J., Tian, J., Ding, C., \& Du, Y. (2020). Modeling repeated 
1083 coseismic slip to identify and characterize individual earthquakes from geomorphic offsets on 1084 strike-slip faults. Earth and Planetary Science Letters, 545, 116313.

1085 https://doi.org/10.1016/j.epsl.2020.116313

1086 Liu-Zeng, J., Klinger, Y., Sieh, K., Rubin, C., \& Seitz, G. (2006). Serial ruptures of the San 1087 Andreas fault, Carrizo Plain, California, revealed by three-dimensional excavations. Journal of 1088 Geophysical Research, 111, B02306.

1089 Lozos, J. C. (2016). A case for historic joint rupture of the San Andreas and San Jacinto faults. 1090 Science Advances, 2(3), e1500621. https://doi.org/10.1126/sciadv.1500621

1091 Manighetti, I., Perrin, C., Dominguez, S., Garambois, S., Gaudemer, Y., Malavieille, J., et al. 1092 (2015). Recovering paleoearthquake slip record in a highly dynamic alluvial and tectonic region 1093 (Hope Fault, New Zealand) from airborne lidar. Journal of Geophysical Research: Solid Earth, 1094 120(6), 4484-4509. https://doi.org/10.1002/2014JB011787

1095 Manighetti, I., Perrin, C., Gaudemer, Y., Dominguez, S., Stewart, N., Malavieille, J., Garambois, 1096 S. (2020). Repeated giant earthquakes on the Wairarapa fault, New Zealand, revealed by Lidar1097 based paleoseismology. Scientific Reports, 10, 2124. https://doi.org/10.1038/s41598-020-59229$1098 \quad 3$

1099 Martin, L. C. P., Blard, P.-H., Balco, G., Lavé, J., Delunel, R., Lifton, N., Laurent, V. (2017).

1100 The CREp program and the ICE-D production rate calibration database: A fully parameterizable 1101 and updated online tool to compute cosmic-ray exposure ages. Quaternary Geochronology, 38, 1102 25-49. https://doi.org/10.1016/j.quageo.2016.11.006

1103 McClusky, S., Balassanian, S., Barka, A., Demir, C., Ergintav, S., Georgiev, I., et al. (2000). 1104 Global Positioning System constraints on plate kinematics and dynamics in the eastern 
1105 Mediterranean and Caucasus. Journal of Geophysical Research: Solid Earth, 105(B3), 569511065719.

1107 McGill, S. F., \& Rubin, C. M. (1999). Surficial slip distribution on the central Emerson fault 1108 during the June 28, 1992, Landers earthquake, California. Journal of Geophysical Research: 1109 Solid Earth, 104(B3), 4811-4833.

1110 McGill, S. F., \& Sieh, K. (1991). Surficial offsets on the Central and Eastern Garlock Fault 1111 associated with prehistoric earthquakes. Journal of Geophysical Research, 96(B13), 21597111221621.

1113 Meade, B. J., Hager, B. H., McClusky, S. C., Reilinger, R. E., Ergintav, S., Lenk, O., et al. 1114 (2002). Estimates of seismic potential in the Marmara Sea region from block models of secular 1115 deformation constrained by Global Positioning System measurements. Bulletin of the 1116 Seismological Society of America, 92(1), 208-215. http://dx.doi.org/10.1785/0120000837

1117 Merchel, S. \& Herpers, U. (1999). An update on radiochemical separation techniques for the 1118 determination of long-lived radionuclides via accelerator mass spectrometry. Radiochimica Acta, $111984(4), 215-219$. https://doi.org/10.1524/ract.1999.84.4.215

1120 Moratto, Z. M., Broxton, M. J., Beyer, R. A., Lundy, M., \& Husmann, K. (2010). Ames Stereo 1121 Pipeline, NASA's Open Source Automated Stereogrammetry Software. Paper presented at the 1122 41th Lunar and Planetary Science Conference, Woodlands, TX.

1123 Motagh, M., Hoffmann, J., Kampes, B., Baes, M., \& Zschau, J. (2007). Strain accumulation

1124 across the Gazikoy-Saros segment of the North Anatolian Fault inferred from Persistent

1125 Scatterer Interferometry and GPS measurements. Earth and Planetary Science Letters, 255, 4321126 444. http://dx.doi.org/10.1016/j.epsl.2007.01.003. 
1127 Onderdonk, N., McGill, S., \& Rockwell, T. (2018). A 3700 yr paleoseismic record from the 1128 northern San Jacinto fault and implications for joint rupture of the San Jancinto and San Andreas 1129 faults. Geosphere, 14(6), 2447-2468. https://doi.org/10.1130/GES01687.1

1130 Özalp, S., Emre, Ö., \& Dogan, A. (2013). The segment structure of southern branch of the North 1131 Anatolian Fault and palaeoseismological behaviour of the Gemlik fault, NW Anatolia. Bulletin of 1132 MTA, 147, 1-17.

1133 Özbey, V., Özeren, M.S., Henry, P., Klein, E., Galgana, G., Karabulut, H., et al. (2021).

1134 Kinematics of the Marmara Region: a fusion of continuum and block models. Mediterranean

1135 Geoscience Reviews, 3, 57-78. https://doi.org/10.1007/s42990-021-00051-y

1136 Öztürk, K., Yaltirak, C., \& Alpar, B. (2009). The relationship between the tectonic setting of the 1137 Lake Iznik Basin and the Middle Strand of the North Anatolian Fault. Turkish Journal of Earth 1138 Sciences, 18, 209-224.

1139 Palyvos, N., Pantosti, D., Zabci, C., \& D’Addezio, G. (2007). Paleoseismological Evidence of 1140 Recent Earthquakes on the 1967 Mudurnu Valley Earthquake Segment of the North Anatolian 1141 Fault Zone. Bulletin of the Seismological Society of America, 97(5), 1646-1661.

1142 https://doi.org/10.1785/0120060049

1143 Parsons, T., Toda, S., Stein, R. S., Barka, A., \& Dieterich, J. H. (2000). Heightened odds of large 1144 earthquakes near Istanbul: An interaction-based probability calculation. Science, 288(5466), 1145 661-665. https://doi.org/10.1126/science.288.5466.661

1146 Pondard, N., Armijo, R., King, G. C. P., Meyer, B., \& Flérit, F. (2007). Fault interactions in the 1147 Sea of Marmara pull-apart (North Anatolian Fault): earthquake clustering and propagating 1148 earthquake sequences. Geophysical Journal International, 171, 1185-1197. 
1149 https://doi.org/10.1111/j.1365-246X.2007.03580.x

1150 Reilinger, R., McClusky, S., Vernant, P., Lawrence, S., Ergintav, S., Cakmak, R., et al. (2006).

1151 GPS constraints on continental deformation in the Africa-Arabia-Eurasia continental collision

1152 zone and implications for the dynamics of plate interactions. Journal of Geophysical Research:

1153 Solid Earth, 111, B05411. doi:10.1029/2005JB004051.

1154 Reitman, N. G., Mueller, K. J., Tucker, G. E., Gold, R. D., Briggs, R. W., \& Barnhart, K. R.

1155 (2019). Offset channels may not accurately record strike-slip fault displacements: Evidence from

1156 landscape evolution models. Journal of Geophysical Research: Solid Earth, 124, 13,427-13,451.

1157 Ren, Z., Zielke, O., \& Yu, J. (2018). Active tectonics in 4D high-resolution. Journal of

1158 Structural Geology, 117, 264-271. https://doi.org/10.1016/j.jsg.2018.09.015

1159 Rizza, M., Ritz, J. F., Braucher, R., Vassallo, R., Prentice, C., Mahan, S., et al. (2011). Slip rate

1160 and slip magnitudes of past earthquakes along the Bogd left-lateral strike-slip fault (Mongolia).

1161 Geophysical Journal International, 186(3), 897-927. https://doi.org/10.1111/j.1365-

$1162 \quad$ 246X.2011.05075.x

1163 Rockwell, T. K., Dawson, T. E., Young Ben-Horin, J., \& Seitz, G. (2014). A 21-Event, 4,000

1164 Year History of Surface Ruptures in the Anza Seismic Gap, San Jacinto Fault, and Implications

1165 for Long-term Earthquake Production on a Major Plate Boundary Fault. Pure and Applied

1166 Geophysics, 172, 1143-1165. https://doi.org/10.1007/s00024-014-0955-z

1167 Rockwell, T. K., Lindvall, S., Dawson, T., Langridge, R., Lettis, W., \& Klinger, Y. (2002).

1168 Lateral Offsets on Surveyed Cultural Features Resulting from the 1999 Izmit and Düzce

1169 Earthquakes, Turkey. Bulletin of the Seismological Society of America, 92(1), 79-94.

1170 https://doi.org/10.1785/0120000809

This article is protected by copyright. All rights reserved. 
1171 Rockwell, T., Ragona, D., Seitz, G., Langridge, R., Ersen Aksoy, M., Ucarkus, G., et al. (2009).

1172 Palaeoseismology of the North Anatolian Fault near the Marmara Sea: Implications for fault

1173 segmentation and seismic hazard. In K. Reicherter, A. M. Michetti, P. G. Silva (Eds.),

1174 Palaeoseismology: Historical and Prehistorical Records of Earthquake Ground Effects for

1175 Seismic Hazard Assessment, Geological Society Special Publications (Vol. 316(1), pp. 31-54).

1176 London: The Geological Society. https://doi.org/10.1144/SP316.3

1177 Scharer, K. M., Salisbury, J. B., Arrowsmith, J. R., \& Rockwell, T. K. (2014). Southern San

1178 Andreas Fault Evaluation Field Activity: Approaches to Measuring Small Geomorphic Offsets -

1179 Challenges and Recommendations for Active Fault Studies. Seismological Research Letters, 85,

1180 68-76. https://doi.org/10.1785/0220130108

1181 Schwartz, D. P., \& Coppersmith, K. J. (1984). Fault Behavior and Characteristic Earthquakes:

1182 Examples From the Wasatch and San Andreas Fault Zones. Journal of Geophysical Research, 1183 89(B7), 5681-5698.

1184 Sengör, A. M. C., Grall, C., Imren, C., Le Pichon, X., Görür, N., Henry, P., et al. (2014). The 1185 geometry of the North Anatolian transform fault in the Sea of Marmara and its temporal 1186 evolution: implications for the development of intracontinental transform faults. Canadian

1187 Journal of Earth Sciences, 51(3), 222-242. https://doi.org/10.1139/cjes-2013-0160

1188 Sengör, A. M. C., Tüysüz, O., Imren, C., Sakinç, M., Eyidogan, H., Görür, N., et al. (2005). The 1189 North Anatolian Fault: A New Look. Annual Review of Earth and Planetary Sciences, 33, 371190 112. https://doi.org/10.1146/annurev.earth.32.101802.120415

1191 Sengör, A. M. C., \& Zabci, C. (2019). The North Anatolian Fault and the North Anatolian Shear 1192 Zone. In C. Kuzucuoglu, A. Ciner, N. Kazanci (Eds.), Landscape and Landforms of Turkey (pp. 
1193 481-494). Cham: Springer International Publishing. https://doi.org/10.1007/978-3-030-03515-

1194 0_27

1195 Shean, D. E., Alexandrov, O., Moratto, Z., Smith, B. E., Joughin, I. R., Porter, C. C., \& Morin, P.

1196 J. (2016). An automated, open-source pipeline for mass production of digital elevation models

1197 (DEMs) from very high-resolution commercial stereo satellite imagery. ISPRS Journal of

1198 Photogrammetry and Remote Sensing, 116, 101-117.

1199 https://doi.org/10.1016/j.isprsjprs.2016.03.012

1200 Sieh, K. E. \& Jahns, R. H. (1984). Holocene activity of the San Andreas fault at Wallace Creek,

1201 California. Geological Society of America Bulletin, 95(8), 883-896.

1202 https://doi.org/10.1130/0016-7606(1984)95<883:HAOTSA>2.0.CO;2

1203 Sipahioglu, S. \& Matsuda, T. (1986). Geology and Quaternary fault in the Iznik-Mekece area. In 1204 A. M. Isikara, Y. Honkura (Eds.), Electric and Magnetic Research on Active Faults in the North 1205 Anatolian Fault Zone. (pp. 25-41). Tokyo: Tokyo Inst. Technology.

1206 Stein, R. S., Barka, A. A., \& Dieterich, J. H. (1997). Progressive failure on the North Anatolian 1207 fault since 1939 by earthquake stress triggering. Geophysical Journal International, 128(3), 5941208 604. https://doi.org/10.1111/j.1365-246X.1997.tb05321.x

1209 Straub, C., Kahle, H.-G., \& Schindler, C. (1997). GPS and geologic estimates of the tectonic 1210 activity in the Marmara Sea region, NW Anatolia. Journal of Geophysical Research: Solid 1211 Earth, 102(B12), 27587-27601.

1212 Stroeven, A. P., Heyman, J., Fabel, D., Björck, S., Caffee, M. W., Fredin, O., \& Harbor, J. M. 1213 (2015). A new Scandinavian reference ${ }^{10}$ Be production rate. Quaternary Geochronology, 29, 1214 104-115. https://doi.org/10.1016/j.quageo.2015.06.011 
1215 Tanoglu, A., \& Erinc, S. (1956). Garsak bogazı ve Eski Sakarya (The Garsak gorge and the

1216 Sakarya River diversion). Istanbul Universitesi Cografya Enstitusu Dergisi, 4, 17-31.

1217 Tsukuda, T., Satake, K., Honkura, Y., Üçer, S. B., \& Isikara, A. M. (1988). Low seismicity, low

1218 coda-Q and discontinuities of the upper crust in the vicinity of the Iznik-Mekece fault, the North 1219 Anatolian Fault Zone, Turkey. Bulletin of Earthquake Research of the Institute University of 1220 Tokyo, 63, 327-348.

1221 Uppala, S. M., KÅllberg, P. W., Simmons, A. J., Andrae, U., Bechtold, V. D. C., Fiorino, M., et 1222 al. (2005). The ERA-40 re-analysis. Quarterly Journal of the Royal Meteorological Society, 131, 1223 2961-3012. https://doi.org/10.1256/qj.04.176

1224 van der Woerd, J., Klinger, Y., Sieh, K., Tapponnier, P., Ryerson, F. J., \& Mériaux, A. S. (2006). 1225 Long-term slip rate of the southern San Andreas Fault from ${ }^{10} \mathrm{Be}-{ }^{26} \mathrm{Al}$ surface exposure dating of 1226 an offset alluvial fan. Journal of Geophysical Research, 111, B04407.

1227 Vardar, D., Öztürk, K., Yaltırak, C., Alpar, B., \& Tur, H. (2014). Late Pleistocene-Holocene 1228 evolution of the southern Marmara shelf and sub-basins: middle strand of the North Anatolian 1229 fault, southern Marmara Sea, Turkey. Marine Geophysical Research, 35(1), 69-85. 1230 https://doi.org/10.1007/s11001-013-9210-8

1231 Ward, S. N. (1997). Dogtails versus rainbows: synthetic earthquake rupture models as an aid in 1232 interpreting geological data. Bulletin of the Seismological Society of America, 87(1), 1422-1441.

1233 Wechsler, N., Rockwell, T. K., \& Klinger, Y. (2018). Variable slip-rate and slip-per-event on a 1234 plate boundary fault: The Dead Sea fault in northern Israel. Tectonophysics, 722, 210-226.

1235 https://doi.org/10.1016/j.tecto.2017.10.017

1236 Wells, D. L., \& Coppersmith, K. J. (1994). New Empirical Relationships among Magnitude, 
1237 Rupture Length, Rupture Width, Rupture Area, and Surface Displacement. Bulletin of the

1238 Seismological Society of America, 84(4), 974-1002.

1239 Wesnousky, S. G. (2006). Predicting the endpoints of earthquake ruptures. Nature, 444, 358-360.

1240 https://doi.org/10.1038/nature05275

1241 Yılmaz, Y., Genç, C., Yigitbas, E., Bozcu, M., \& Yılmaz, K. (1995). Geological evolution of the

1242 late Mesozoic continental margin of Northwestern Anatolia. Tectonophysics, 243(1), 155-171.

1243 https://doi.org/10.1016/0040-1951(94)00196-G

1244 Yoshioka, T. \& Kusçu, I. (1994). Late Holocene faulting events on the Iznik-Mekece fault in the

1245 western part of the North Anatolian fault zone, Turkey. Bulletin of the Geological Survey of

1246 Japan, 45(11), 677-685.

1247 Zabc1, C. (2019). Spatio-temporal behaviour of continental transform faults: Implications from

1248 the late Quaternary slip history of the North Anatolian Fault, Turkey. Canadian Journal of Earth

1249 Sciences, 56(11), 1218-1238. https://doi.org/10.1139/cjes-2018-0308

1250 Zabci, C., Sançar, T., Akyüz, H. S., \& Kiyak, N. G. (2015). Spatial slip behavior of large strike-

1251 slip fault belts: Implications for the Holocene slip rates of the eastern termination of the North

1252 Anatolian Fault, Turkey. Journal of Geophysical Research: Solid Earth, 120(12), 8591-8609.

1253 Zielke, O. (2018). Earthquake Recurrence and the Resolution Potential of Tectono-Geomorphic

1254 Records. Bulletin of the Seismological Society of America, 108(3A), 1399-1413.

1255 https://doi.org/10.1785/0120170241

1256 Zielke, O., Arrowsmith, J. R., Grant Ludwig, L., \& Akçiz, S. O. (2010). Slip in the 1857 and

1257 earlier large earthquakes along the Carrizo Plain, San Andreas Fault. Science, 327, 1119-1122.

1258 https://doi.org/10.1126/science.1182781

This article is protected by copyright. All rights reserved. 
1259 Zielke, O., Arrowsmith, J. R., Grant Ludwig, L., \& Akciz, S. O. (2012). High-Resolution

1260 Topography-Derived Offsets along the 1857 Fort Tejon Earthquake Rupture Trace, San Andreas

1261 Fault. Bulletin of the Seismological Society of America, 102(3), 1135-1154.

1262 https://doi.org/10.1785/0120110230

1263 Zielke, O., Klinger, Y., \& Arrowsmith, J. R. (2015). Fault slip and earthquake recurrence along 1264 strike-slip faults - Contributions of high-resolution geomorphic data. Tectonophysics, 638, 431265 62. https://doi.org/10.1016/j.tecto.2014.11.004

1266

This article is protected by copyright. All rights reserved. 